June 2002

\title{
FOSTER CARE
}

Recent Legislation

Helps States Focus on

Finding Permanent

Homes for Children,

but Long-Standing

Barriers Remain

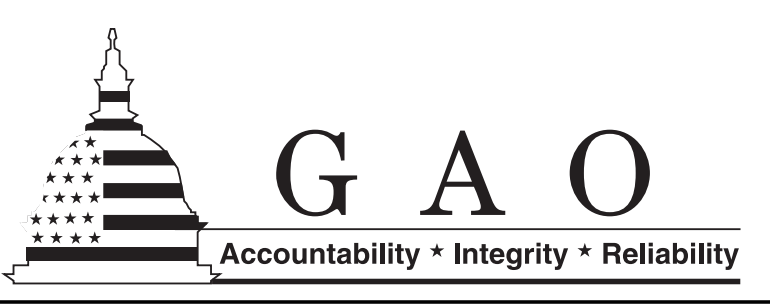




\section{Contents}

\section{Letter}

Results in Brief

Background

Limited Data are Available to Measure Changes in the Outcomes and Characteristics of Children Since ASFA

Although Little Data are Available on Key ASFA Permanency Provisions, Some States Describe Circumstances That Limit Broader Use of These Provisions

New ASFA Adoption-Related Funds Most Commonly Used to Recruit Adoptive Families and Provide Post Adoption Services

States Develop Practices in Response to Long-Standing Barriers That Continue to Hamper Efforts to Promote Permanency for Foster Children $\quad 36$

$\begin{array}{ll}\text { Conclusions } & 43\end{array}$

Recommendation to the Secretary of Health and Human Services 44

Agency Comments

Appendix I

Scope and Methodology

Appendix II

Summary of Child Welfare Demonstration Waivers

Appendix III

Comments from the Department of Health and Human Services

Appendix IV

GAO Contacts and Acknowledgments

GAO Contacts

55

Acknowledgments

Bibliography 


\section{Tables}

Table 1: Ten States at Least Doubled Annual Average Adoptions after ASFA

Table 2: Length of Stay for All Children Exiting Foster Care, Fiscal Year 1998-Fiscal Year 2000

Table 3: Length of Stay for Children Adopted From Foster Care, Fiscal Year 1998-Fiscal Year 2000

Table 4: Number of Foster Care Placements for All Children Exiting Foster Care, Fiscal Year 1998-Fiscal Year 2000

Table 5: Number of Foster Care Placements for Children Adopted From Foster Care, Fiscal Year 1998-Fiscal Year 2000

Table 6: Exit Destinations for All Children Leaving Foster Care, Fiscal Year 1998-Fiscal Year 2000

Table 7: Percentage of Children Who Re-enter Foster Care after Reunifying with Their Families, Fiscal Year 1998-Fiscal Year 2000

Table 8: Race/Ethnicity of Children Adopted from Foster Care, Fiscal Year 1998-Fiscal Year 2000

Table 9: Ages of Children Adopted from Foster Care, Fiscal Year 1998-Fiscal Year 2000

Table 10: Fiscal Year 2000 Data From Four States That Responded to Survey Questions on Their Use of ASFA's Fast Track Provision

Table 11: Fiscal Year 2000 Data from Nine States That Responded to Survey Questions on Their Use of ASFA's 15 of 22 Provision

Table 12: Reasons for Not Filing a TPR for a Child Who Had Been in Foster Care for 15 of the Most Recent 22 Months in Fiscal Year 2000, Based on Seven States That Responded to Survey Questions on the 15 of 22 Provision

Table 13: Main Uses of Adoption Incentive Payments and PSSF Adoption Promotion and Support Services Funds

Table 14: Approved Child Welfare Demonstration Waivers and Key Dates

\section{Figure}

Figure 1: Number of Children Adopted from Foster Care between Fiscal Year 1995 and Fiscal Year 2000 


\begin{tabular}{ll}
\hline Abbreviations \\
ACF & Administration for Children and Families \\
AFCARS & Adoption and Foster Care Analysis and Reporting System \\
ASFA & Adoption and Safe Families Act of 1997 \\
CAPTA & Child Abuse Prevention and Treatment Act \\
CFSR & Child and Family Services Review \\
CY & calendar year \\
FY & federal fiscal year \\
GAO & General Accounting Office \\
HHS & Health and Human Services \\
PSSF & Promoting Safe and Stable Families \\
SFY & state fiscal year \\
TPR & termination of parental rights \\
VCIS & Voluntary Cooperative Information System
\end{tabular}


June 28, 2002

The Honorable Wally Herger

Chairman, Subcommittee on Human Resources

Committee on Ways and Means

House of Representatives

The Honorable Max Baucus

United States Senate

The Honorable Lincoln D. Chafee

United States Senate

The Honorable Larry E. Craig

United States Senate

The Honorable Mike DeWine

United States Senate

The Honorable Charles E. Grassley

United States Senate

The Honorable Mary L. Landrieu

United States Senate

The Honorable John D. Rockefeller IV

United States Senate

In the mid-1990s, some children languished in temporary foster care while prolonged attempts were made to reunify them with their families. In response to concerns about the length of time children were spending in foster care, the Congress enacted the Adoption and Safe Families Act of 1997 (ASFA). ASFA contained two key provisions that were intended to help states more quickly move the more than 800,000 children estimated to spend some time in foster care each year to safe and permanent homes. One of these provisions, referred to as "fast track," allows states to bypass efforts to reunify families in certain egregious situations. The other provision, informally called " 15 of 22 ," requires states to file a petition to 
terminate parental rights (TPR) when a child has been in foster care for 15 of the most recent 22 months. ${ }^{1}$ In addition, ASFA emphasized the importance of adoption when foster children cannot safely and quickly return to the care of their families. Toward that end, ASFA established incentive payments for states that increase their adoptions. In addition, the law provided a new source of funds for states to use to promote and support adoptions through the Promoting Safe and Stable Families (PSSF) program.

Because of your interest in how states have implemented ASFA and what its impact has been on permanency outcomes for children in foster care, you asked us to review key provisions in the legislation. Specifically, you asked us to determine (1) how the outcomes and characteristics of children in foster care have changed since ASFA was enacted, (2) how states have used ASFA's fast track and 15 of 22 provisions, (3) how states are spending new adoption-related funds provided by ASFA, and (4) what states are doing to address barriers to achieving permanency.

To conduct our work, we analyzed national child welfare data sets and statistical reports. To supplement these statistics, we surveyed all 50 states and the District of Columbia regarding foster care outcomes, ${ }^{2}$ the use of ASFA's fast track and 15 of 22 provisions, expenditures of ASFA adoptionrelated funds, and efforts to address barriers to finding permanent homes for children. We received responses from 46 states, although they did not all respond to every question. ${ }^{3}$ We also reviewed a variety of Department of Health and Human Services (HHS) Administration for Children and Families' (ACF) documents and interviewed federal officials and child welfare experts on ASFA's impact. In addition, we visited six statesIllinois, Maryland, Massachusetts, North Carolina, Oregon, and Texas-to obtain first-hand information on ASFA's effect on state child welfare agencies. We selected these states to represent a range of locations and levels of performance under the adoption incentive program. We also

\footnotetext{
${ }^{1}$ ASFA allows for some exceptions to this provision. For example, states are not required to file a TPR for a child who has been in foster care for 15 months if the child is in a relative's care.

${ }^{2}$ Throughout this report, references to state survey responses include the District of Columbia.

${ }^{3}$ In addition, we requested survey data by federal fiscal year (FY) for 1999 and 2000. However, of the 46 states responding to our survey, 22 provided data for time periods other than FY 1999 and FY 2000, such as calendar year (CY) or state fiscal year (SFY).
} 
chose to visit some states that had implemented innovative practices in their child welfare systems. We conducted our work between June 2001 and April 2002 in accordance with generally accepted government auditing standards. A more detailed discussion of our scope and methodology appears in appendix I. was enacted, changes in other foster care outcomes and the characteristics of children in foster care cannot be identified due to the lack of comparable pre- and post-ASFA data. Foster care adoptions increased from approximately 31,000 in 1997 to over 48,600 in 2000, continuing a trend of increasing finalized adoptions that started before ASFA. However, data limitations make it difficult to determine either ASFA's role in this increase or changes in other foster care outcomes. For example, reliable pre-ASFA child welfare data for several states are available from the University of Chicago, but they cannot be matched against the post-ASFA data available from HHS due to differences in measurement techniques. Nevertheless, examination of HHS data between 1998 and 2000 provides insight into the characteristics and outcomes of children in foster care after ASFA was enacted. For example, children who left foster care between 1998 and 2000 spent a median of nearly 1 year in care. Of these children, those who were adopted spent more time in foster care-a median of approximately $31 / 2$ years. Children most frequently returned home after a stay in care, but approximately 33 percent of children who reunified with their families in 1998 re-entered foster care within 3 years. Although these data illustrate the experiences of foster children since ASFA, recent improvements in HHS data make it difficult to determine if changes observed after 1998 are the result of changes in data quality or actual changes in the outcomes and characteristics of foster children.

Although data on states' use of ASFA's two key permanency provisionsfast track and 15 of 22-are limited, some states described circumstances that hindered the broader use of these provisions. In response to our survey, very few states were able to provide specific information on the number of children affected by these provisions and HHS does not require states to collect this data. Survey data from a few states suggest that they use the fast track provision infrequently. Most of the states we visited reported using fast track for a small number of children, primarily those who have experienced serious abuse or whose parents previously had parental rights to other children terminated. However, state officials described several court-related issues, such as reluctance on the part of 
some judges to allow the state to bypass reunification efforts, which prevented these states from using it in more cases. In addition, survey responses from nine states indicated that they exempted a number of children-ranging from 31 to 2,919 in 2000-from the 15 of 22 provision. The states we visited similarly reported exempting many children, such as adolescents and children with serious medical needs for whom locating adoptive parents would take a long time. Other children exempted included those placed with relatives and those who were expected to reunify shortly with their families. The states we visited reported that the timeframe of the 15 of 22 provision was helpful in facilitating more timely decisions on permanent placements for children.

In general, states are most frequently using the new adoption-related funds provided by ASFA to recruit adoptive parents and provide post adoption services. For example, Connecticut used its adoption incentive funds to buy advertisements on Spanish language television to recruit adoptive families for older Hispanic children and sibling groups to address a shortage of families for these children. Likewise, North Carolina used its PSSF funds to hire private agencies to recruit adoptive families for certain groups of children. Oregon, on the other hand, used its PSSF funds to create a new, statewide resource center to provide information and referral services, support groups, and educational workshops to adoptive families. In addition to recruitment and post adoption programs, we found that states have spent these ASFA funds on a variety of other child welfare activities, including hiring and training social workers.

The states we visited have implemented a variety of practices to address long-standing barriers to achieving permanency for foster children. These barriers include court delays and insufficient court resources, difficulties in recruiting adoptive families for children with special needs, obstacles and delays in placing children in permanent homes in other jurisdictions, and poor access to some services families need to reunify with their children. States are testing different approaches to address these barriers, but limited data are available on the effectiveness of these practices. For example, Massachusetts has developed a mediation program to help families and potential adoptive parents agree on the permanent plan for a child, thereby avoiding the time associated with a court trial and an appeal of the court's decision. However, only preliminary evaluation results are available on this program. Under HHS's child welfare demonstration waiver program, four states are experimenting with approaches to improve access to treatment services for parents with substance abuse problems. Final evaluation results for the first waiver project were 
published in April 2002, but results for most of the existing waiver projects will not be available for a few years.

To obtain a clearer understanding of how ASFA's two key permanency provisions are working, we are recommending that the Secretary of HHS consider ways to obtain information on states' use of ASFA's fast track and 15 of 22 provisions. In commenting on this report, ACF generally agreed with our findings and recommendation. ACF noted that it has established a team to review data issues and that the team plans to evaluate the feasibility of including data on ASFA's fast track and 15 of 22 provisions in its existing adoption and foster care data system.

The foster care system has grown dramatically in the past two decades, with the number of children in foster care nearly doubling since the mid1980s. Concerns about children's long stays in foster care culminated in the passage of ASFA in 1997, which emphasized the child welfare system's goals of safety, permanency, and child and family well-being. The Administration for Children and Families (ACF) at HHS is responsible for the administration and oversight of federal funding to states for child welfare services under Titles IV-B and IV-E of the Social Security Act. In 2000, ACF established a new federal review system to monitor state compliance with federal child welfare laws. One component of this system is the Child and Family Services Review (CFSR), which assesses state performance in achieving the three goals ASFA emphasized. The CFSR process includes a self-assessment by the state, an analysis of state performance in meeting national standards established by HHS and an onsite review by a joint team of federal and state officials. ${ }^{4}$

Two titles under the Social Security Act provide federal funding targeted specifically to foster care and related child welfare services. ${ }^{5}$ Title IV-E provides an open-ended individual entitlement for foster care maintenance payments to cover a portion of the food, housing, and incidental expenses for all foster children whose parents meet certain federal eligibility

\footnotetext{
${ }^{4}$ Examples of HHS standards include the percent of foster children who are the subject of a substantiated or indicated report of abuse or neglect by a foster parent and the percent of children who re-enter foster care within 12 months of a prior foster care episode.

${ }^{5}$ In addition, Title XX provides funds under the social services block grant that may be used for many purposes, including child welfare.
} 
criteria. ${ }^{6}$ Title IV-E also provides payments to adoptive parents of eligible foster children with special needs. ${ }^{7}$ Special needs are characteristics that can make it more difficult for a child to be adopted and may include emotional, physical or mental disabilities, emotional disturbance, age, being a member of a sibling group, or being a member of a minority race. Title IV-B provides limited funding for child welfare services to foster children, as well as children remaining in their homes. In federal fiscal year 2001, total Title IV-E spending was $\$ 5.6$ billion and total Title IV-B spending was $\$ 576$ million. move into safe, permanent placements those foster children who are unable to safely return home in a reasonable amount of time. Under the fast track provision, states are not required to pursue efforts to prevent removal from home or to return a child home if a parent has (1) lost parental rights to that child's sibling; (2) committed specific types of felonies, including murder or voluntary manslaughter of the child's sibling; or (3) subjected the child to aggravated circumstances, such as abandonment, torture, chronic abuse, or sexual abuse. In these egregious situations, the courts may determine that services to preserve or reunite the family - that is, the "reasonable efforts" requirement established in the Adoption Assistance and Child Welfare Act of 1980 (Public Law 96-272)are not required. Once the court makes such a determination, the state must begin within 30 days to find the child an alternative permanent family or other permanent arrangement. In addition, the Abandoned Infants Assistance Act of 1988, as amended in 1996, requires states to expedite the termination of parental rights for abandoned infants in order to receive priority to obtain certain federal funds.

The second provision requires states to file a TPR with the courts if (1) an infant has been abandoned; (2) the parent committed any of the felonies

\footnotetext{
${ }^{6}$ In addition, certain judicial findings must be present for the child in order for the child to be eligible for Title IV-E foster care maintenance payments.

${ }^{7}$ To qualify for an adoption subsidy under Title IV-E, a state must determine that the child cannot or should not return home; a state must make a reasonable, but unsuccessful effort to place the child without the subsidy; and a specific factor or condition must exist that makes it difficult to place the child without a subsidy. States have the discretion to define the specifics of the special needs category.

${ }^{8}$ Throughout this report, fiscal year refers to federal fiscal year, unless noted otherwise.
} 
listed in the fast track provision; or (3) the child has been in foster care for 15 of the most recent 22 months. ${ }^{9}$ States may exempt children from this requirement if the child is placed with a relative; the state has not provided services needed to make the home safe for the child's return; or the state documents a compelling reason that filing a TPR is not in the child's best interest.

ASFA also contained other provisions to help states focus on the length of time children were remaining in care. For example, ASFA requires states to hold a permanency planning hearing for each child in foster care at least every 12 months, during which the court determines the future plans for a child-for example, whether the state should continue to pursue reunification with the child's family or begin to pursue some other permanency goal. Prior to ASFA, these permanency hearings had been required to occur by the 18th month of a child's stay in care. For those children who will not be reunified with their families, ASFA also requires that the permanency plan document the steps taken to place the child and finalize the adoption or legal guardianship. At a minimum, the permanency plan must document any child-specific recruitment efforts taken to find an adoptive family or legal guardian for a child.

In addition, ASFA includes three provisions that are specific to interjurisdictional adoption issues. These provisions (1) require assurances in state plans ${ }^{10}$ that a state will not delay or deny the placement of a child for adoption when an approved family is available in a different state or locality, (2) require assurances that the state will develop plans for the effective use of cross-jurisdictional resources to facilitate permanent placements of waiting children, and (3) make ineligible for certain federal funds any state that is found to deny or delay the placement of a child for adoption when an approved family is available in another jurisdiction. ${ }^{11}$

\footnotetext{
${ }^{9}$ Under ASFA a child is considered to have entered care on the earlier of (1) the date of the first judicial finding that the child has been subjected to child abuse or neglect or (2) 60 calendar days after the date on which the child is removed from the home.

${ }^{10}$ State plans are required under Title IV-E of the Social Security Act in order for states to receive federal foster care funds for maintenance of foster children, specific administrative costs associated with foster care programs, and adoption assistance.

${ }^{11}$ ASFA also makes ineligible for certain federal funds any state that fails to promptly grant a fair hearing to an individual who alleges such a violation.
} 
New Funds Introduced by ASFA
ASFA also authorized a new funding source dedicated to adoption-related activities. Prior to ASFA, the Congress established the family preservation and family support program under subpart 2 of Title IV-B of the Social Security Act, authorizing funds to provide two categories of services: family preservation and community-based family support services. ASFA reauthorized the program, renaming it Promoting Safe and Stable Families (PSSF) and adding two new funding categories: adoption promotion and support services and time-limited family reunification services. HHS program instructions specify that states must have a strong rationale for spending less than 20 percent of their PSSF funds on each of the four defined categories. The Congress authorized $\$ 305$ million for the PSSF program in fiscal year 2001. A research firm found that state expenditures of federal PSSF funds on adoption promotion and support activities increased from $\$ 50$ million in fiscal year 1999 to $\$ 79$ million in fiscal year 2001, representing a 58 percent increase. ${ }^{12}$ In January 2002, the PSSF program was reauthorized, authorizing $\$ 305$ million for each of fiscal years 2002 through 2006, along with an additional $\$ 200$ million in discretionary grant funds for each of those years.

ASFA created the adoption incentive payment program, which financially rewards states for increasing numbers of finalized adoptions. The states have the flexibility to use the incentive payment funds for any child welfare related initiative. To benefit from the incentive payment, states must exceed an adoption baseline established for their particular state. The baseline for the initial award year — fiscal year 1998 — was each state's average number of finalized adoptions in fiscal years 1995, 1996, and 1997. After fiscal year 1998, a state's baseline is based on any previous fiscal year that has the largest number of finalized adoptions, beginning with fiscal year 1997. States receive a fixed payment of $\$ 4,000$ for each foster child who is adopted over the baseline and an extra $\$ 2,000$ for each adopted child characterized as having a special need. States have earned a total of more than $\$ 127$ million in incentive payments for adoptions finalized in fiscal years 1998, 1999 and 2000.

ASFA expanded the use of federal child welfare demonstration waivers that allow states to test innovative foster care and adoption practices. In 1994, the Congress gave HHS the authority to establish up to 10 child

\footnotetext{
${ }^{12}$ James Bell Associates, Analysis of States' Annual Progress and Services Reports and Child and Family Services Plans (1999-2001): The Family Preservation and Family Support Services (FP/FS) Implementation Study (Arlington, Va., 2002).
} 
welfare demonstrations that waive certain restrictions in Titles IV-B and IV-E of the Social Security Act and allow broader use of federal funds. ASFA authorized 10 additional waivers in each year between fiscal years 1998 and 2002 to ensure that more states had the opportunity to test innovations. States with an approved waiver must conduct a formal evaluation of the project's effectiveness and must demonstrate the waiver's cost neutrality - that is, a state cannot spend more in Title IV-B and IV-E funds than it would have without the waiver. Projects generally are to last no more than 5 years. Although funding for this program is scheduled to end in fiscal year 2002, the Congress expects to consider its reauthorization later this year.

Child Welfare Data Systems
HHS compiles data on children in foster care and children who have been adopted from state child welfare agencies in the Adoption and Foster Care Analysis and Reporting System (AFCARS) ${ }^{13}$ HHS is responsible for collecting and reporting data and verifying their quality. States began submitting AFCARS data to HHS in 1995. Twice a year, states are required to submit data on the characteristics of children in foster care, foster parents, adopted children and adoptive parents. Prior to AFCARS, child welfare data was collected in the Voluntary Cooperative Information System (VCIS), operated by what was then called the American Public Welfare Association. ${ }^{14}$ Since reporting to VCIS was not mandatory, the data in the system were incomplete. In addition, the data submitted were inconsistent because states used reporting periods and definitions for various data elements that differed from each other.

\footnotetext{
${ }^{13}$ The Children's Bureau, under ACF, is the HHS component responsible for compiling these data.

${ }^{14}$ In 1998, the American Public Welfare Association became the American Public Human Services Association (APHSA).
} 
Limited Data are Available to Measure Changes in the Outcomes and Characteristics of Children Since ASFA
The number of annual adoptions has increased since the implementation of ASFA; however, data limitations restrict comparative analysis of other outcomes and characteristics of children in foster care ${ }^{15}$ Foster care adoptions grew from 31,004 in fiscal year 1997 to 48,680 in fiscal year 2000, representing an increase of 57 percent since ASFA was enacted. ${ }^{16}$

However, current data constraints make it difficult to determine what role ASFA played in this increase. The lack of reliable and comparable pre- and post-ASFA data at this time limits our ability to analyze how other foster care outcomes or children's characteristics have changed. For example, reliable pre-ASFA child welfare data are available from the University of Chicago for a limited number of states ${ }^{17}$ but they cannot be matched against the post-ASFA data available from HHS. Current data do, however, provide some information about the characteristics and experiences of foster children after ASFA. For example, children leaving care between 1998 and 2000 spent a median of approximately 1 year in care. Of these children, those who were adopted spent more time in foster care-a median of approximately $31 / 2$ years. Children most frequently returned home after a stay in care, but about 33 percent of those children re-entered foster care within 3 years.

\section{Adoptions Have Increased Since ASFA, but Changes in Other Outcomes Unclear}

Adoptions from state child welfare foster care programs have increased nationwide by 57 percent since ASFA was implemented, while changes in other outcomes are less clearly discernible. Adoptions began to increase prior to the enactment of federal child welfare reforms (see fig. 1). For example, between 1995 and 2000, annual adoptions of children in foster

\footnotetext{
${ }^{15} \mathrm{HHS}$ officials believe that the adoption data available as early as 1995 are more reliable than early data on other outcomes because of the incentive payments that states can earn for increasing adoptions. They noted that states made great efforts to improve the accuracy of their adoption data when the incentive payment baselines were established. For example, HHS initially estimated about 20,000 adoptions for FY 1997, but after states reviewed and submitted their adoption data, as required for participation in the adoption incentive program, they reported about 31,000 adoptions.

${ }^{16}$ All HHS data are presented in terms of federal fiscal year.

${ }^{17}$ The University of Chicago has data that tracks foster children in 12 states. One state has provided data since 1975, 7 states have provided data since the 1980s, and 4 states have provided data since the 1990 s.
} 
care increased by 89 percent from approximately 26,000 to nearly $49,000 .^{18}$ Adoptions generally increased between 8 percent and 12 percent year to year between 1995 and 2000, except in 1999 when they increased by 29 percent over 1998 adoptions. This increase in overall adoptions of children in foster care is accompanied by a parallel increase in the adoptions of children with special needs.

Figure 1: Number of Children Adopted from Foster Care between Fiscal Year 1995 and Fiscal Year 2000

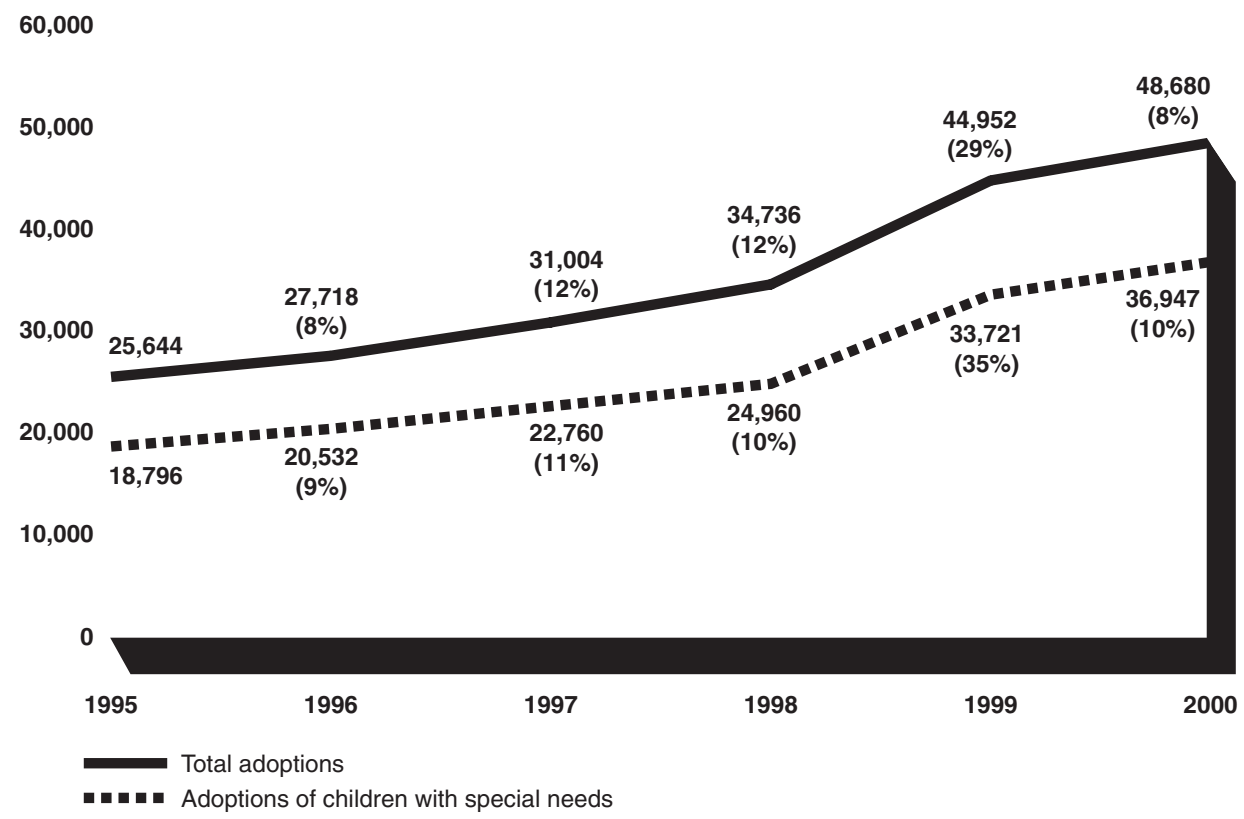

Note: The percentages in parentheses represent the increase in finalized adoptions over the previous year.

Source: Data from HHS's Children's Bureau used to determine adoption incentive payments.

In at least one of the 3 years following the implementation of ASFA, all states increased their adoptions over the average number of adoptions finalized between 1995 and 1997. This average represents the baseline

\footnotetext{
${ }^{18}$ The data represented in this analysis were compiled by HHS and the states in response to the adoption incentive payment program created by ASFA. Initial eligibility for participation in the incentive program was based on states reporting adoption data from $\mathrm{FY}$ 1995 through FY 1997. An average of these years was taken to establish a baseline number of adoptions. Adoption data prior to FY 1995 are considered unreliable.
} 
established for each state for participation in the adoption incentive program. A comparison of the states' baselines with their average number of adoptions for the 3 years following ASFA shows that 10 states at least doubled the annual average number of adoptions between 1998 and 2000 (see table 1).

Table 1: Ten States at Least Doubled Annual Average Adoptions after ASFA

\begin{tabular}{lrrr}
\hline & \multicolumn{2}{c}{ Average annual adoptions } & Percent change \\
\cline { 2 - 3 } State & FY 1995-1997 & FY 1998-2000 & $\begin{array}{r}\text { over baseline } \\
\text { Hawaii }\end{array}$ \\
\hline Wyoming & 85 & 274 & 222 \\
\hline Illinois & 15 & 40 & 167 \\
\hline Oklahoma & 2,200 & 5,786 & 163 \\
\hline Maine & 338 & 768 & 127 \\
\hline North Dakota & 108 & 240 & 122 \\
\hline Minnesota & 47 & 104 & 122 \\
\hline Mississippi & 258 & 527 & 104 \\
\hline Arkansas & 114 & 232 & 104 \\
\hline Texas & 138 & 280 & 103 \\
\hline
\end{tabular}

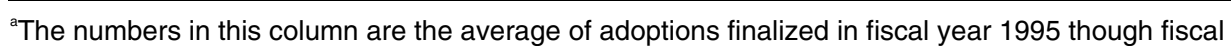
year 1997. HHS used this average as the states' adoption baseline for the initial year of the adoption incentive payment program.

Source: Data from the HHS's Children's Bureau used to determine adoption incentive payments.

The role ASFA played in the increase in adoptions after 1997, however, is unclear. Similarly, whether the number of foster children being adopted will continue to rise in the future is unknown. While ASFA may have contributed to the adoptions of these children, other factors may have also played a role. For example, HHS officials have noted that earlier state child welfare reform efforts may be linked to the observed increase in adoptions. To better understand why adoptions have increased and to evaluate ASFA's impact, HHS has asked the University of Chicago to use its data from several states to track groups of foster children over time to determine if the percentage of children adopted from foster care has changed and if adoptions occur more quickly now. Since it can take several years for foster children to be adopted, and ASFA has only been in existence for a few years, evidence of ASFA's effect may not be available for some time.

ASFA's effect on other foster care outcomes, such as family reunifications, is also difficult to determine. Lack of comparable and reliable data on 
foster children, before and after ASFA, make it difficult to know how ASFA has affected the child welfare system. While HHS officials report that some data are reliable and can provide a picture of children in foster care post-ASFA, they state that the child welfare data covering pre-ASFA periods are not reliable. According to HHS data specialists, early data available suffered from problems such as low response rates and data inconsistencies.

Since 1998, however, HHS data specialists have observed marked improvements in the data submitted to HHS by states and attribute the changes to several factors. These factors include the provision of federal technical assistance to the states on data processing issues and the use of federal financial penalties and incentives. ${ }^{19}$ HHS data specialists also note that states are improving their data in response to the use of outcome measures in the Child and Family Services Reviews and the annual publication of child welfare outcomes for each state. According to HHS, these data improvements make it impossible to determine whether observed changes in outcomes from one year to the next are the result of changes in data quality or changes in state performance. HHS expects that the data will stabilize over time and can eventually be used as a reliable measure of state performance.

Although HHS cannot provide reliable pre-ASFA data, research conducted at the University of Chicago provides reliable pre-ASFA information on some foster care outcomes for 12 states. However, the University of Chicago's pre-ASFA data cannot be compared with HHS's post-ASFA data. Unlike other child welfare data sources that collect periodic data on children in care ${ }^{20}$ the University of Chicago's system follows all of the children entering foster care in an individual year and collects data on them until they leave to determine their final outcomes. This approach provides accurate information on the experiences of all foster children over time and does not over represent the experiences of certain children,

\footnotetext{
${ }^{19}$ In January 2002, the Assistant Secretary of the Administration for Children and Families at HHS repealed the penalties issued for non-compliance with AFCARS submissions. The decision came after 12 states jointly appealed the penalties and the presiding officer of the hearing, appointed by the Assistant Secretary, recommended their withdrawal. HHS data specialists expressed concern about the consequences the repeal might have on AFCARS data quality if noncomplying states are not penalized. However, HHS officials report that they will continue to monitor data quality and state compliance in the absence of penalties.

${ }^{20}$ Other child welfare data sources include AFCARS and VCIS.
} 
such as those who stay in care for extended periods of time. ${ }^{21}$ However, the use of this different measurement technique prevents comparisons of the University of Chicago's pre-ASFA data with HHS's post-ASFA data.

\section{Current Data Describe Characteristics and Experiences of Children Who Exited Care between 1998 and 2000}

\section{Foster Care Trends}

\begin{abstract}
Although pre-ASFA data are limited and more time is needed to determine how ASFA has affected the child welfare system, current data do shed some light on the characteristics and experiences of the more than 741,000 children who exited foster care between 1998 and $2000 .{ }^{22}$ According to HHS data for this time period, children left foster care after a median length of stay of approximately 1 year. Prior to leaving foster care, children typically lived in 1 or 2 foster care placements and a very small portion of them were abused or neglected by their foster care providers. Most foster children reunified with their families; however, approximately 33 percent of the children who went home to their families in 1998 subsequently returned to foster care within 3 years, for reasons such as additional abuse and neglect at home. A smaller percentage of children left foster care through adoption. The majority of children adopted from foster care were under age 12 and classified as having special needs. Limited evidence suggests that few adopted children returned to the child welfare system.
\end{abstract}

About half of the children leaving foster care exit within one year; however, the data show slight changes in the length of children's stays during 1998-2000 (see table 2). In 1998, the median length of stay for children exiting care was 11 months-by 2000, it had risen to 12 months. In contrast, the median length of stay for adopted children dropped from 43 months in 1998 to 39 months in 2000 (see table 3). Determining whether

\footnotetext{
${ }^{21} \mathrm{AFCARS}$ and VCIS are point-in-time data systems and therefore only capture children who are in foster care at the time the data are reported. As a result, these systems can report either the experiences of children currently in care or the experiences of children who have exited care, but cannot track the experiences of all children served in foster care over a certain timeframe. When collecting data on children currently in care, children with longer stays are over represented in the data set, biasing the measured outcomes. Similarly, when collecting data on children who exit care, the overall lengths of stay for children exiting care tend to appear shorter due to the over representation of children with shorter lengths of stay, biasing the outcomes in the opposite direction. Consequently, the AFCARS and VCIS outcome measures vary depending on the group observed.

${ }^{22}$ According to HHS's AFCARS data, 223,255 children exited foster care in FY 1998 from 44 states (including the District of Columbia and Puerto Rico); 250,950 exited foster care in FY 1999 from 51 states (including the District of Columbia and Puerto Rico); and 267,344 exited foster care in FY 2000 from 51 states (including the District of Columbia).
} 
these shifts represent real changes in the amount of time children spend in foster care or whether they simply reflect the recent improvements in HHS data is difficult. Twenty-three states reported in our survey that in fiscal year 2000 adopted children spent an average of 18 months living with the family that eventually adopted them prior to their adoption being finalized. ${ }^{23}$

Table 2: Length of Stay for All Children Exiting Foster Care, FY 1998-2000

\begin{tabular}{|c|c|c|c|}
\hline \multirow[b]{2}{*}{ Time in foster care } & \multicolumn{3}{|c|}{ Percentage of all children exiting foster care } \\
\hline & FY $1998^{a}$ & FY $1999^{b}$ & FY 2000 \\
\hline Less than 1 month & $19 \%$ & $19 \%$ & $18 \%$ \\
\hline 1-11 months & 31 & 31 & 31 \\
\hline $12-23$ months & 18 & 18 & 18 \\
\hline $24-35$ months & 9 & 10 & 11 \\
\hline 3-4 years & 11 & 11 & 11 \\
\hline 5 years or more & 10 & 10 & 10 \\
\hline Data missing $^{d}$ & 2 & 1 & 1 \\
\hline
\end{tabular}

${ }^{a}$ Based on data from 44 states (including the District of Columbia and Puerto Rico).

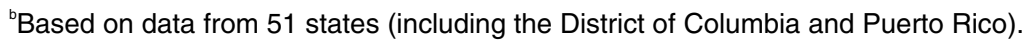

${ }^{\circ}$ Based on data from 51 states (including the District of Columbia).

d"Data missing" indicates that a child exited foster care, but the length of stay is not available.

Source: AFCARS data from HHS's Children's Bureau. ${ }^{23}$ One of the 23 states reporting on the length of time children lived with the family that
eventually adopted them provided CY 2000 data. 
Table 3: Length of Stay for Children Adopted From Foster Care, FY 1998-2000

\begin{tabular}{|c|c|c|c|}
\hline \multirow[b]{2}{*}{ Time in foster care } & \multicolumn{3}{|c|}{$\begin{array}{c}\text { Percentage of children adopted from foster } \\
\text { care }\end{array}$} \\
\hline & FY $1998^{\mathrm{a}}$ & FY $1999^{b}$ & FY $2000^{\circ}$ \\
\hline 0 to 12 months $^{d}$ & $8 \%$ & $7 \%$ & $5 \%$ \\
\hline 13 to 24 months & 14 & 16 & 17 \\
\hline 25 to 36 months & 19 & 20 & 24 \\
\hline 37 to 48 months & 18 & 17 & 19 \\
\hline More than 4 years & 41 & 39 & 34 \\
\hline
\end{tabular}

Note: Percentages do not always total to 100 due to rounding.

${ }^{\text {a}}$ Based on data from 49 states (including the District of Columbia and Puerto Rico).

${ }^{\mathrm{b}}$ Based on data from 52 states (including the District of Columbia and Puerto Rico).

${ }^{\mathrm{c} B a s e d}$ on data from 52 states (including the District of Columbia and Puerto Rico).

${ }^{\mathrm{d} S}$ Some of the children adopted after less than a year in foster care are infants. During our site visit to Texas, child welfare workers reported that infants abandoned by their families are generally adopted by the time they are 6 or 7 months old.

Source: AFCARS data from HHS's Children's Bureau.

The amount of time children spend in foster care varies from state to state. For example, the median length of stay for children exiting care in Delaware was about 5 months in 2000, while in Illinois it was close to 4 years in 2000. Differences in state foster care stays may be linked to child welfare practices. For example, higher adoption rates can play a role in increasing the median length of stay figures, since adopted children stay in foster care for longer periods of time. Conversely, higher reunification rates can play a role in decreasing the median length of stay, since reunified children spend less time in foster care. In Delaware, most children who left care reunified with their families and only a small percentage were adopted. In contrast, Illinois had lower reunification rates and one of the highest yearly adoption rate averages in the country. Illinois officials explained that they work extensively with families to prevent the need for foster care and only bring children into care when these efforts have failed. Consequently, although data are not available, Illinois officials believe that the children in their care are less likely to reunify with their families than foster children in other states that they believe may not work as extensively with families before children are removed from their homes.

Before they leave foster care, most children live in one or two different placements (see table 4). Many children have only one placement during their foster care stay, but a few experience five or more placements. 
Adopted children tend to experience a greater number of foster care placements (see table 5). Adopted children may have more foster care placements than other children, in part, because of their longer foster care stays. According to some researchers, children experience more placements the longer they are in foster care. ${ }^{24}$

Table 4: Number of Foster Care Placements for All Children Exiting Foster Care, FY1998-2000

\begin{tabular}{lrrr}
\hline & \multicolumn{3}{c}{ Percentage of all children exiting foster care } \\
\cline { 2 - 4 } Number of foster care placements & FY 1998 & FY $\mathbf{1 9 9 9}^{\mathbf{a}}$ & $\mathbf{F Y ~ 2 0 0 0}^{\mathbf{c}}$ \\
\hline 1 & $\mathbf{4 2 \%}$ & $46 \%$ & $\mathbf{4 4 \%}$ \\
\hline 2 & 20 & 22 & $\mathbf{2 2}$ \\
\hline 3 & 10 & 11 & 11 \\
\hline 4 & 5 & 6 & 6 \\
\hline 5 or more & 10 & 11 & 10 \\
\hline Data missing $^{d}$ & 13 & 4 & 7 \\
\hline
\end{tabular}

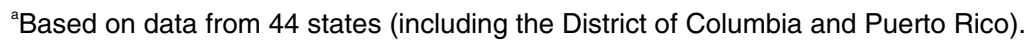

${ }^{b}$ Based on data from 51 states (including the District of Columbia and Puerto Rico).

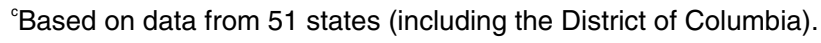

"Data missing" indicates that a child exited foster care, but the number of placements is not available.

Source: AFCARS data from HHS's Children's Bureau.

\footnotetext{
${ }^{24}$ Kathy Barbell and Madelyn Freundlich, Foster Care Today (Washington, D.C.: Casey Family Programs, 2001).
} 
Table 5: Number of Foster Care Placements for Children Adopted From Foster Care, FY 1998-2000

\begin{tabular}{|c|c|c|c|}
\hline \multirow[b]{2}{*}{ Number of foster care placements } & \multicolumn{3}{|c|}{ Percentage of adopted children } \\
\hline & FY $1998^{a}$ & FY $1999^{b}$ & FY $2000^{\circ}$ \\
\hline 1 & $20 \%$ & $20 \%$ & $24 \%$ \\
\hline 2 & 22 & 26 & 26 \\
\hline 3 & 13 & 15 & 17 \\
\hline 4 & 8 & 10 & 10 \\
\hline 5 or more & 12 & 14 & 14 \\
\hline Data missing $^{d}$ & 24 & 15 & 9 \\
\hline
\end{tabular}

Note: Percentages do not always total to 100 due to rounding.

${ }^{\text {a} B a s e d ~ o n ~ d a t a ~ f r o m ~} 49$ states (including the District of Columbia and Puerto Rico).

${ }^{\mathrm{b}}$ Based on data from 52 states (including the District of Columbia and Puerto Rico).

'Based on data from 52 states (including the District of Columbia and Puerto Rico).

"'Data missing" indicates that a child was adopted from foster care, but the number of foster care placements is not available.

Source: AFCARS data from HHS's Children's Bureau.

During their foster care stays, a small percentage of children are abused or neglected by their caregivers. Our survey results ${ }^{25}$ indicate that the median percentage of children abused or neglected while in foster care during 1999 and 2000 was 0.60 percent and 0.49 percent, respectively.

Maltreatment rates in foster care in 2000 ranged from a high of 2.74 percent in the District of Columbia to a low of 0.02 percent in Nebraska. ${ }^{26}$

On average, less than one-third of the children in foster care exit each year. Children exit foster care in a number of ways, including reunifying

\footnotetext{
${ }^{25}$ Of the 46 states that responded to our survey, 16 provided data on the percentage of foster children who had a substantiated report of abuse or neglect in FY 1999, 2 provided data for CY 1999, 1 provided data for SFY 1999, 18 provided data for FY 2000, 1 provided data for CY 2000, and 2 provided data for SFY 2000.

${ }^{26}$ According to HHS's Child Welfare Outcomes 1999: Annual Report, the median percentage of foster children abused and neglected while in care was 0.5 percent for the 20 states reporting. Maltreatment rates in foster care range from a high of 2.3 percent in Rhode Island to a low of 0.1 percent in Arizona, Delaware and Wyoming.
} 
with their families,${ }^{27}$ being adopted, emancipation, ${ }^{28}$ or entering a guardianship arrangement ${ }^{29}$ (see table 6). Upon leaving foster care, most children returned home to the families they had been living with prior to entering foster care. However, a number of these children re-entered foster care for a number of reasons, such as additional abuse and neglect by their families (see table 7).

Table 6: Exit Destinations for All Children Leaving Foster Care, FY 1998-2000

\begin{tabular}{|c|c|c|c|}
\hline \multirow[b]{2}{*}{ Exit destination } & \multicolumn{3}{|c|}{ Percentage of all children exiting foster care } \\
\hline & FY $1998^{a}$ & FY $1999^{b}$ & FY $2000^{\circ}$ \\
\hline Reunification & $48 \%$ & $55 \%$ & $55 \%$ \\
\hline Adoption & 12 & 15 & 16 \\
\hline Living with other relative & 7 & 9 & 9 \\
\hline Emancipation & 5 & 7 & 7 \\
\hline Guardianship & 2 & 3 & 4 \\
\hline Transfer to another agency & 3 & 3 & 3 \\
\hline Runaway & 2 & 2 & 2 \\
\hline Death of child & 0 & 0 & 0 \\
\hline Data missing $^{d}$ & 21 & 6 & 4 \\
\hline
\end{tabular}

${ }^{a}$ Based on data from 44 states (including the District of Columbia and Puerto Rico).

${ }^{\mathrm{b}}$ Based on data from 51 states (including the District of Columbia and Puerto Rico).

${ }^{\mathrm{C} B a s e d}$ on data from 51 states (including the District of Columbia).

"'Data missing" indicates that a child exited foster care, but the exit destination was not reported.

Source: AFCARS data from HHS's Children's Bureau.

\footnotetext{
${ }^{27}$ In AFCARS, reunification is defined as the child returning to the family with whom the child had been living prior to entering foster care.

${ }^{28} \mathrm{~A}$ child is emancipated from foster care when the child reaches majority age according to state law.

${ }^{29}$ Guardianship arrangements occur when permanent legal custody is awarded to an individual, such as a relative.
} 
Table 7: Percentage of Children Who Re-enter Foster Care after Reunifying with Their Families, FY1998-2000

\begin{tabular}{lrrr}
\hline & $\begin{array}{r}\text { Percent who re- } \\
\text { entered foster } \\
\text { care in FY 1998 }\end{array}$ & $\begin{array}{r}\text { Percent who re- } \\
\text { entered foster } \\
\text { care in FY 1999 }\end{array}$ & $\begin{array}{r}\text { Percent who re- } \\
\text { entered foster } \\
\text { care in FY 2000 }\end{array}$ \\
\hline $\begin{array}{l}\text { Children who reunified with } \\
\text { families in FY 1998 }\end{array}$ & 18 & 11 & 4 \\
\hline $\begin{array}{l}\text { Children who reunified with } \\
\text { families in FY 1999 }\end{array}$ & d & 15 & 10 \\
\hline $\begin{array}{l}\text { Children who reunified with } \\
\text { families in FY 2000 }\end{array}$ & d & d & 14 \\
\hline
\end{tabular}

a'Based on data from 44 states (including the District of Columbia and Puerto Rico).

${ }^{\mathrm{b}}$ Based on data from 51 states (including the District of Columbia and Puerto Rico).

${ }^{c}$ Based on data from 51 states (including the District of Columbia).

${ }^{\mathrm{d}}$ Not applicable.

Source: AFCARS data from HHS's Children's Bureau.

Adoption Trends

Although most children reunify with their families, the second most common way of exiting foster care is through adoption. The children adopted from foster care have a wide variety of characteristics, yet the data indicate some general themes. Most children adopted from foster care have at least one special need that may make placing a child with an adoptive family challenging. ${ }^{30}$ On average, 85 percent of the children adopted in 1998, 1999, and 2000 were classified as having at least one special need that would qualify them for adoption subsidies under Title IVE. ${ }^{31}$ Eighteen states reported in our survey that, on average, 32 percent of

\footnotetext{
${ }^{30}$ Our discussion of special needs in this report focuses on the determination of special needs of adopted children for eligibility for adoption assistance under Title IV-E of the Social Security Act. Therefore, an equivalent measure is not available for children in foster care.

${ }^{31}$ While current AFCARS data indicate that 85 percent of children adopted in FY 1998 through FY 2000 have at least one special need, the adoption incentive data presented earlier in figure 1 indicate a lower proportion of children with special needs adopted from foster care. An HHS official explained that this discrepancy is due to the timing of the measurement of the data. The data in figure 1 were measured at an earlier point in time and the numbers are not updated since adoption incentive payments are awarded to states based on the number of finalized adoptions reported at the end of each fiscal year. The data presented here reflect changes to AFCARS based on states resubmitting previous data after the initial reporting periods and are as recent as April 2002. In addition, the HHS official explained that different groups of children are included in the AFCARS and adoption incentive program data regarding children with special needs. Only children who are eligible for adoption assistance under Title IV-E are included in the special needs category for the adoption incentive program. AFCARS data on children with special needs,
} 
the children adopted from foster care in 2000 had three or more special needs. ${ }^{32}$ In addition, according to HHS data, children adopted from foster care are equally likely to be male or female, slightly more likely to be black (see table 8), and much more likely to be under age 12 (see table 9). The gender and race/ethnicity distributions of children in foster care are similar to those for children who are adopted. However, the age distribution differs between the two groups of children. For example, in 1999, approximately 46 percent of the children in foster care were 11 years or older.

Table 8: Race/Ethnicity of Children Adopted from Foster Care, FY1998-2000

\begin{tabular}{lrrr}
\hline & \multicolumn{3}{c}{ Percentage of children adopted from foster care } \\
\cline { 2 - 4 } Race/Ethnicity & FY 1998 & FY $\mathbf{1 9 9 9}^{\mathbf{b}}$ & FY 2000 $^{\mathbf{c}}$ \\
\hline White (non-Hispanic) & $38 \%$ & $35 \%$ & $38 \%$ \\
\hline Black (non-Hispanic) & 42 & 41 & 39 \\
\hline Hispanic & 12 & 14 & 14 \\
\hline $\begin{array}{l}\text { Asian/Pacific Islander/American } \\
\text { Indian/Alaskan Native }\end{array}$ & 2 & 2 & 2 \\
\hline Unknown/Data missing $^{\mathrm{d}}$ & 5 & 8 & 7 \\
\hline
\end{tabular}

Note: Percentages do not always total to 100 due to rounding.

${ }^{\text {a } B a s e d ~ o n ~ d a t a ~ f r o m ~} 49$ states (including the District of Columbia and Puerto Rico).

${ }^{\mathrm{b}}$ Based on data from 52 states (including the District of Columbia and Puerto Rico).

${ }^{\mathrm{c} B a s e d}$ on data from 52 states (including the District of Columbia and Puerto Rico).

"Data missing" indicates that a child was adopted from foster care, but the race or ethnicity is not available.

Source: AFCARS data from HHS's Children's Bureau.

however, include children who are eligible for adoption assistance either through the Title IV-E program or through an individual state's adoption assistance program.

${ }^{32}$ One of the 18 states reporting on the number of children adopted with three or more special needs provided data based on CY 2000. 
Table 9: Ages of Children Adopted from Foster Care, FY1998-2000

\begin{tabular}{lrrr}
\hline & \multicolumn{3}{c}{ Percentage of children adopted from foster care } \\
\cline { 2 - 4 } Age at adoption & FY 1998 & FY 1999 & ${\text { FY } \mathbf{2 0 0 0}^{\mathbf{c}}}^{\mathbf{b}}$ \\
\hline Under 1 year & $1 \%$ & $1 \%$ & $1 \%$ \\
\hline 1 to 5 years & 46 & 45 & 46 \\
\hline 6 to 11 years & 41 & 41 & 40 \\
\hline 12 to 15 years & 10 & 11 & 11 \\
\hline 16 years and older & 2 & 2 & 2 \\
\hline
\end{tabular}

${ }^{\mathrm{a} B a s e d}$ on data from 49 states (including the District of Columbia and Puerto Rico).

${ }^{b}$ Based on data from 52 states (including the District of Columbia and Puerto Rico).

${ }^{\circ}$ Based on data from 52 states (including the District of Columbia and Puerto Rico).

Source: AFCARS data from the HHS's Children's Bureau.

As noted for other outcomes, the lack of reliable and national pre-ASFA data make it difficult to determine whether the rate at which adoptions encountered problems has changed since ASFA was enacted.$^{33}$ However, limited data suggest that problems occur in a small percentage of foster care adoptions. According to our survey, ${ }^{34}$ about 5 percent of adoptions planned in fiscal years 1999 and 2000 disrupted prior to being finalized. ${ }^{35}$ States also reported that approximately 1 percent of adoptions finalized in these years legally dissolved at a later date and that about 1 percent of the children who were adopted in these years subsequently re-entered foster

\footnotetext{
${ }^{33}$ Studies on adoption problems prior to ASFA's enactment have several limitations, such as small samples sizes, coverage of a few locations, and a focus on narrowly defined groups of children.

${ }^{34}$ Of the 46 states that responded to our survey, 17 provided data on adoption disruptions for FY 1999, 2 provided data for CY 1999, 18 provided data on adoption disruptions for FY 2000, and 2 provided data for CY 2000.

${ }^{35}$ For example, Illinois reported a 12.4 percent disruption rate for FY 1999 on our survey. In comparison, one study (Robert Goerge and others, Adoption, Disruption, and Displacement in the Child Welfare System, 1976-1995 (Chicago: Chapin Hall Center for Children at the University of Chicago, 1995)) reviewed all planned and finalized adoptions in Illinois between 1981 and 1987. During that time, an average of 9.9 percent of adoption plans for Illinois foster children disrupted.
} 
care.$^{36}$ However, little time has elapsed since these adoptions were finalized and some of these adoptions may legally dissolve at a later date. HHS data similarly indicate that about 1 percent of the children entering foster care each year have previously been adopted. States reported in our survey that adopted children return to foster care for different reasons, including abuse or neglect by their adopted families, behavior problems which are too difficult for their adoptive families to handle, or a child's need for residential care.

Although Little Data are Available on Key ASFA Permanency Provisions, Some States Describe Circumstances That Limit Broader Use of These Provisions
While few states were able to provide data on the numbers of children affected by ASFA's fast track and 15 of 22 provisions, some reported on circumstances that make it difficult to use these provisions for more children. In addition, HHS collects very little data on the use of these provisions. Data from four states that provided fast track data in response to our survey indicate that they do not use this provision frequently. Officials at our site visits told us that they use the fast track provision for a small number of children, primarily those who have experienced serious abuse or whose parents had involuntarily lost parental rights for other siblings. However, they described several court-related issues that make it difficult to fast track more children, including court delays and a reluctance on the part of some judges to relieve the state from reunification efforts. Survey responses from the few states that provided data on the 15 of 22 provision indicate that these states do not file TPRs for many children who are in care for 15 months. Officials at the six states we visited believe that ASFA's 15 of 22 time standard has helped them make more timely permanency decisions, but reported that they exempt many children from this requirement for a number of reasons, including difficulties in finding adoptive parents.

\footnotetext{
${ }^{36}$ Of the 46 states that responded to our survey, 18 provided data on dissolutions for FY 1999, 19 provided data on dissolutions for FY 2000 and 1 provided data for CY 2000. In addition, 21 states provided survey data on foster care re-entries by children adopted in FY 1999, 22 provided data for children adopted in FY 2000, and 1 provided data for children adopted in CY 2000. Our survey results indicate that of all the children with finalized adoptions in FY 1999, 0.55 percent returned to foster care in FY 1999 or 2000 . Of all the children with finalized adoptions in FY 2000, 1.43 percent returned to foster care in FY 2000 .
} 
While Data on Fast Track Are Limited, Some States Report Court-Related Issues That Hinder the Use of the Fast Track Provision for More Children
Few states were able to provide data on their use of the fast track provision in response to our survey and HHS does not collect this data from the states. As a result, we do not have sufficient information to discuss the extent to which states are using this provision. As shown in table 10, the data from a handful of states suggest the infrequent use of fast track. In fiscal year 2000, for example, about 4,000 children entered the child welfare system in Maryland, but only 36 were fast tracked. Child welfare officials in the six states we visited told us that they used ASFA's fast track provision for a relatively small number of cases. Three states indicated that they fast tracked abandoned infants, while four states reported using fast track for cases involving serious abuse, such as when a parent has murdered a sibling; however, some state officials also noted that few child welfare cases involve these circumstances. In addition, five states reported that they would fast track certain children whose parents had involuntarily lost parental rights to previous children if no indication exists that the parents have addressed the problem that led to the removal of the children.

Table 10: Fiscal Year 2000 Data From Four States That Responded to Survey Questions on Their Use of ASFA's Fast Track Provision

\begin{tabular}{|c|c|c|c|c|c|}
\hline \multirow[b]{2}{*}{ State } & \multirow[b]{2}{*}{$\begin{array}{l}\text { Number of children } \\
\text { who entered care }\end{array}$} & \multicolumn{4}{|c|}{ Number of children who were fast-tracked, by category } \\
\hline & & $\begin{array}{r}\text { Aggravated } \\
\text { circumstances }\end{array}$ & $\begin{array}{r}\text { Felony } \\
\text { conviction }\end{array}$ & $\begin{array}{r}\text { Previous } \\
\text { TPR }\end{array}$ & Total \\
\hline Maryland & 3,928 & 19 & 15 & 2 & 36 \\
\hline Massachusetts & 7,381 & a & a & a & 25 \\
\hline Vermont & 788 & 0 & 0 & 0 & 0 \\
\hline West Virginia & 2,392 & 13 & 0 & 28 & 41 \\
\hline
\end{tabular}

an its survey response, Massachusetts reported the total number of children who were fast tracked, but did not provide data on the different fast track categories.

Source: GAO survey and AFCARS data.

Officials in five of the states we visited described several court-related issues that hindered the greater use of the fast track provision. However, because of the lack of data on states' use of fast track, we were unable to determine the extent of these problems. Officials in these states told us that some judges or other legal officials are at times reluctant to approve a state's fast track request. According to officials in Massachusetts, North Carolina, and Maryland, some judges believe that parents should always be given the opportunity to reunify with their children. According to child welfare staff for a county in North Carolina, the courts had recently denied the county's request to fast track several cases and ordered the county to provide services to the families involved. In one case, a judge approved a 
fast track request involving a child who had suffered from shaken baby syndrome, but refused a similar request on a sibling who was born a few months after the shaking episode. County staff stated that the judge's decision was based on the fact that the parents had not hurt the newborn and should be given an opportunity to demonstrate their ability to care for this child.

Three states we visited described other court problems related to the fast track provision. For example, state officials in North Carolina told us that delays in scheduling TPR trials in the state undermine the intent of fast tracking. They noted that the agency may save time by not providing services to a family, but the child may not be adopted more quickly if it takes 12 months to schedule the TPR trial. Officials in Massachusetts expressed similar concerns about court delays experienced in the state when parents appeal a court decision to terminate their parental rights. Finally, a Massachusetts official explained that the state is cautious about using the fast track provision due to concerns that not providing services to parents could undermine their TPR case. According to a Massachusetts official, the state obtained court approval to fast track a case, but subsequently lost the TPR trial in part because the judge found that the parents did not receive services to help them reunify with their child.

Other difficulties in using fast track to move children out of foster care more quickly are related to the specific categories of cases that are eligible to be fast tracked. Officials in five states told us that they look at several factors when considering the use of fast track for a parent who has lost parental rights for other children. In some of these cases, a different birth father may be involved. Child welfare officials told us that they are obligated to work with the father to determine if he is willing and able to care for the child. According to Maryland officials, if the agency is providing services to the father to facilitate reunification, pursuing a fast track case for the mother will not help the child leave foster care more quickly. In addition, child welfare officials in Massachusetts and Illinois emphasized that a parent who has addressed the problems that led to a previous TPR should have an opportunity to demonstrate the ability to care for a subsequent child. For example, they would not necessarily fast track a substance-abusing mother who lost custody of a previous child if she has engaged in treatment and addressed her parenting issues.

Regarding the fast track category involving parents who have been convicted of certain felonies, child welfare officials in Massachusetts and Texas described this provision as impractical due to the time it takes to obtain a conviction. Massachusetts officials told us that, in most cases, the 
children are removed at the time the crime is committed and judges will not approve the fast track in these cases until the parent is actually convicted, which is usually at least a year after the actual crime. As a result, the state must provide services to reunify the family until further evidence of the parent's unfitness is documented. Finally, in Massachusetts, Texas, and Maryland, officials reported that it can be difficult to prove that a parent subjected a child to aggravated circumstances, such as torture or sexual abuse. According to these officials, the time and effort to go through additional court hearings to demonstrate the aggravated circumstances is not worthwhile; instead, the child welfare agency chooses to provide services to the family.

In response to our survey, three states provided information about why they did not fast track cases that fell into one of the fast track categories, citing reasons that were similar to those reported by our site visit states. For example, Minnesota estimated that in 25 percent of the cases, the state was working to reunify the children with the noncustodial parent. In an additional 25 percent of the cases, the court did not approve the state's request to fast track the case. In the remaining cases, Minnesota did not consider fast track to be in the child's best interests. A Minnesota official explained that in certain circumstances, the agency would try to reunify a family, even if the parents had subjected the child to aggravated circumstances or lost custody of a previous child. For example, if a parent assaulted a child resulting in a broken bone-which would be considered aggravated circumstances under Minnesota law - the agency might not consider a TPR to be in the child's best interests if the assault was a single incident for which the parent accepted responsibility and the child has otherwise had a positive relationship with his or her parent. In addition, the state might not fast track a child born to a mother who had lost custody of a previous child, if the TPR occurred years before and the mother's circumstances had since improved.

\begin{abstract}
Although Little Data Exist on 15 of 22, Some States Report That Many Children Are Exempted
\end{abstract}

Most states do not collect data on their use of ASFA's 15 of 22 provision. In response to our survey, only nine states were able to provide information on the number of children for whom the state filed a TPR due to the 15 of 22 provision or the number of children who were exempted from this provision. In addition, HHS does not systematically track this data. As part of its Child and Family Services Reviews (CFSR), HHS collects some limited information on the 15 of 22 provision. Specifically, HHS asks each state to discuss its compliance with the 15 of 22 provision and directly assesses compliance during its on-site review of a limited number of case 
records, if the case under review involves a child who has been in care for 15 months. ${ }^{37}$

For most of the states that provided data on their use of the 15 of 22 provision in response to our survey, the number of children exempted from the provision greatly exceeded the number of children to whom it was applied (see table 11). For example, while Oklahoma filed over 1,000 TPRs primarily because the child had been in foster care for 15 of the most recent 22 months, it did not file a TPR for an additional 2,900 children. Similarly, in 1999, we reported on states' efforts to review all children who were already in foster care for 15 months when ASFA was enacted to determine if a TPR should be filed or to document an exemption if a TPR was not appropriate, as required by ASFA. The 12 states that had data reported exempting 60 percent of the children they reviewed..$^{38}$

Table 11: Fiscal Year 2000 Data from Nine States That Responded to Survey Questions on Their Use of ASFA's 15 of 22 Provision

\begin{tabular}{|c|c|c|c|c|}
\hline State & $\begin{array}{l}\text { Number of children } \\
\text { in foster care for at } \\
\text { least part of the year }\end{array}$ & $\begin{array}{l}\text { Total number } \\
\text { of TPRs filed }\end{array}$ & $\begin{array}{r}\text { Number of TPRs filed } \\
\text { primarily because child } \\
\text { was in care for } \\
5 \text { of } 22 \text { months }\end{array}$ & $\begin{array}{r}\text { Number of children in } \\
\text { care } 15 \text { of } 22 \text { months } \\
\text { exempted from } \\
\text { requirement to file a } \\
\text { TPR }\end{array}$ \\
\hline District of Columbia & 3,369 & 183 & 135 & 2,097 \\
\hline Maryland & 16,223 & 1,094 & 520 & 823 \\
\hline Mississippi & 5,018 & 449 & 170 & 31 \\
\hline Oklahoma & 13,762 & 1,612 & 1,027 & 2,919 \\
\hline Oregon & 12,011 & 317 & $\mathrm{a}$ & 1,496 \\
\hline Rhode Island & 3,590 & 351 & $\mathrm{a}$ & 600 \\
\hline Utah & 4,069 & 281 & a & 632 \\
\hline West Virginia & 5,644 & 431 & $\mathrm{~b}$ & 35 \\
\hline Wyoming & 1,409 & 45 & $\mathrm{a}$ & 287 \\
\hline
\end{tabular}

${ }^{a}$ Not available.

${ }^{b}$ West Virginia reported that it filed 375 TPRs for children who had been in foster care for 15 of the most recent 22 months. However, being in care for 15 of the most recent 22 months was not necessarily the primary reason for filing the TPR.

Source: GAO survey.

\footnotetext{
${ }^{37}$ In addition, prior to the CFSR site visit to a state, ACF provides the state with an approximation of the number of children potentially impacted by the 15 of 22 provision, based on a state's AFCARS data.

${ }^{38}$ U.S. General Accounting Office, Foster Care: States' Early Experiences Implementing the Adoption and Safe Families Act, GAO/HEHS-00-1 (Washington, D.C.: Dec. 22, 1999).
} 
Officials in all six site visit states told us that establishing specific timeframes for making permanency decisions about children in foster care has helped their child welfare agencies focus their priorities on finding permanent homes for children more quickly. Two of the states we visited-Texas and Massachusetts - created procedures prior to ASFA to review children who had been in care for a certain length of time and decide whether continued efforts to reunify a family were warranted. Other states had not established such timeframes for making permanency decisions before the 15 of 22 provision was enacted. The director of one state child welfare agency told us that, prior to ASFA, the agency would work with families for years before it would pursue adoption for a child in foster care. In response to ASFA's requirement to hold permanency hearings every 12 months for children in foster care, five of the states we visited emphasized that they now try to make decisions about a child's permanent placement by the time the child has been in care for 12 months. The director of one state child welfare agency noted that the 15 of 22 provision does not fit well with other child welfare timeframes-he stated that having more frequent permanency hearings would force states to make more timely decisions and would be less administratively awkward to implement.

Officials in Oregon, Maryland, and North Carolina stated that that the pressure of these new timeframes has helped child welfare staff work more effectively with parents, informing parents up front about what actions they have to take in the next 12 to 15 months in order to reunify with their children. Conversely, private agency staff in three states expressed concern that pressure from these timeframes could push the child welfare agency and the courts to make decisions too quickly for some children. In one state, for example, staff with a private agency that recruits adoptive families for the state were worried that making decisions so quickly may lead to more children re-entering foster care after being adopted or reunified with their families.

Child welfare officials in the six states we visited described several circumstances under which they would not file a TPR on a child who was in care for 15 of the most recent 22 months. In five of the six states, these officials told us that the provision is difficult to apply to children with special needs for whom adoption may not be a realistic option, such as adolescents and children with serious emotional or behavioral problems. Officials from Maryland and North Carolina reported that, in many cases, the child welfare agency exempts these children from the provision because either the agency or the courts do not consider it to be in their 
best interest to be legal orphans-that is, to have their relationship to their parents legally terminated, but have no identified family ready to adopt them. ${ }^{39}$ State officials in Oregon told us that state law requires that parental rights be terminated solely for the purpose of adoption, so as to avoid creating legal orphans. Officials in other states said that while the child welfare agency would like to pursue a TPR, some courts are not willing to do so unless a potential adoptive family has been identified for the child.

Officials in four states noted that many adolescents remain in long-term foster care. In some cases, they have strong ties to their families, even if they cannot live with them, and will not consent to an adoption.$^{40}$ In other cases, the teenager is functioning well in a stable situation with a relative or foster family that is committed to the child but unwilling to adopt. ${ }^{41}$ For example, officials in a child welfare agency for a county in North Carolina told us about a potentially violent 16-year old foster child who had been in a therapeutic foster home for 10 years. The family was committed to fostering the child, but did not want to adopt him because they did not have the financial resources to provide for his medical needs and because they did not want to be responsible for the results of his actions.

Similarly, four states reported difficulties in recruiting adoptive families for children with severe behavioral or medical problems who will require long-term treatment in a residential facility. State officials in Massachusetts told us that some of these children have such severe problems that they are not ready to live in a family setting. Staff in a county child welfare office in North Carolina told us that mentally ill children whose parents voluntarily place them in state custody because they cannot afford the residential services their children require are generally exempted from the 15 of 22 provision.

In Illinois, child welfare staff told us that some parents need a little more than 15 months to address the problems that led to the removal of their

\footnotetext{
${ }^{39}$ In North Carolina, child welfare agency staff may recommend to the court that a child be exempted from the 15 of 22 provision; according to state officials, however, North Carolina requires that a judge determine that one of the exceptions exists.

${ }^{40}$ All the states we visited require that children over a certain age consent to their adoption. For example, Maryland requires that children 10 years or older consent to their adoption.

${ }^{41}$ ASFA specifically allows states to exempt children placed with relatives from the 15 of 22 provision.
} 
children. If the child welfare agency is reasonably confident that the parents will be able to reunify with their children in a few months, the agency will not file a TPR for a child who has been in foster care for 15 months. Similarly, staff in a county child welfare office in North Carolina told us about two cases involving adolescent children in long-term foster care who became pregnant and had a child while in foster care. In these cases, the adolescent mothers remained in foster care with their children. Staff explained that these young mothers needed more than 15 months to be able to parent their children independently, given their own troubled pasts. As long as the mothers were making reasonable progress in parenting their children, the state would not file a TPR on these infants even though they were in foster care for more than 15 months. One of the mothers had recently reunified with her child, now 2 years old, and was expected to regain legal custody of the child shortly.

Child welfare officials in four states observed that parents must have access to needed services, particularly substance abuse treatment, soon after a child enters care in order for the child welfare system to determine if reunification is a realistic goal by the time a child has been in care for 15 months. Officials in Texas, Oregon, and Maryland reported that the lack of appropriate substance abuse treatment programs that address the needs of parents makes it difficult to get parents in treatment and stable by the 15th month. Juvenile court judges in Massachusetts and Oregon told us that they would not necessarily pursue a TPR when a child has been in care for 15 of the most recent 22 months if parents are engaged in substance abuse treatment and showing progress toward reunification.

State officials in Massachusetts, North Carolina, and Maryland noted that delays in scheduling TPR trials and delays in hearing appeals of TPR decisions can undermine the use of the 15 of 22 provision to achieve permanency for children in a timely manner. For example, Massachusetts officials noted that appeals of TPR decisions face significant delayssimply scheduling the appeal trial can take a year.

In response to our survey, a few states provided explanations regarding why they did not file a TPR on children who had been in care for 15 of the most recent 22 months. The reasons reported by seven states were similar to those reported during our site visits, although they varied significantly among the seven states (see table 12). For example, the District of Columbia estimated that it did not file a TPR for about 60 percent of the children who were in care for 15 months because the state expected that these children would soon be reunified with their parents. In contrast, Rhode Island reported that 600 children were in care for 15 months 
without having a TPR filed and estimated that 67 percent of them were adolescents with permanent plans of either independent living or longterm foster care.

Table 12: Reasons for Not Filing a TPR for a Child Who Had Been in Foster Care for 15 of the Most Recent 22 Months in Fiscal Year 2000, Based on Seven States That Responded to Survey Questions on the 15 of 22 Provision

Estimates of percentage of children who were in foster care for 15 of the most recent 22 months and for whom state did not file a TPR for various reasons

\begin{tabular}{|c|c|c|c|c|c|c|c|}
\hline Reason & $\begin{array}{l}\text { District of } \\
\text { Columbia }\end{array}$ & Minnesota $^{a}$ & Mississippi & Oklahoma & $\begin{array}{l}\text { Rhode } \\
\text { Island }\end{array}$ & $\begin{array}{r}\text { West } \\
\text { Virginia }\end{array}$ & Wyoming \\
\hline Child will not consent to adoption & $0 \%$ & $45 \%$ & $3 \%$ & $0 \%$ & $0 \%$ & $23 \%$ & $8 \%$ \\
\hline $\begin{array}{l}\text { Child expected to soon reunify with } \\
\text { parents }\end{array}$ & 60 & 3 & 0 & 0 & 32 & 0 & 0 \\
\hline $\begin{array}{l}\text { Adolescents in independent living or } \\
\text { long-term foster care }\end{array}$ & 0 & 0 & 0 & 0 & 67 & 0 & 0 \\
\hline Age & 25 & 0 & 0 & 0 & 0 & 0 & 0 \\
\hline $\begin{array}{l}\text { Parents may voluntarily relinquish } \\
\text { parental rights }\end{array}$ & 0 & 0 & 57 & 0 & 0 & 6 & 0 \\
\hline $\begin{array}{l}\text { Child in foster care as a result of } \\
\text { delinquency or juvenile justice } \\
\text { proceeding }\end{array}$ & 0 & 0 & 0 & 0 & 0 & 43 & 0 \\
\hline $\begin{array}{l}\text { Not in child's best interest for other } \\
\text { reasons }\end{array}$ & 10 & 0 & 6 & 0 & 0 & 0 & 18 \\
\hline Child placed with relatives & 5 & 45 & 25 & 33 & 2 & 11 & 17 \\
\hline $\begin{array}{l}\text { State did not provide needed } \\
\text { services }\end{array}$ & 0 & 2 & 9 & 24 & 0 & 17 & 0 \\
\hline Other & 0 & 5 & 0 & 43 & 0 & 0 & 57 \\
\hline
\end{tabular}

Note: Percentages do not total to 100 percent due to rounding.

${ }^{\mathrm{a}}$ Minnesota reported data for CY 2000.

Source: GAO survey. 
New ASFA AdoptionRelated Funds Most Commonly Used to Recruit Adoptive Families and Provide Post Adoption Services
States reported in our survey that they most commonly used their adoption incentive payments and PSSF adoption promotion and support services funds to recruit adoptive parents and to provide post adoption services. For example, Arizona has used its incentive payments to fund performance-based contracts that reward agencies for finding adoptive families for groups of siblings, children aged 10 or older and those from minority groups. ${ }^{42}$ Utah, on the other hand, has used its PSSF funds to sponsor a post adoption Web site for adoptive families. In addition to recruitment and post adoption services, we found that states have spent these ASFA funds on a variety of other child welfare activities, including hiring and training social workers. ${ }^{43}$

Our survey results on states' use of new adoption-related funds mirror findings from a recent study, ${ }^{44}$ which found that the top two uses of incentive payments were for the recruitment of adoptive families and the provision of post adoption services (see table 13). For example, states are using ASFA's adoption-related funds to pursue a variety of activities to recruit adoptive parents. Child welfare officials in all of the states we visited reported that they are struggling to recruit adoptive families for older children and those with severe behavioral or medical problems. To meet this challenge, states are investing in activities designed to match specific foster children with adoptive families, as well as general campaigns to recruit adoptive families. Child specific recruitment efforts include: featuring children available for adoption on television, hosting matching parties for prospective adoptive parents to meet children available for adoption, and taking pictures and videos of foster children to show to prospective families. Massachusetts used its incentive payments to fund recruitment videos to feature the 20 children who had been waiting the longest for adoptive families, while Nebraska used its incentive funds to improve the profiles of waiting children on its state Web site.

\footnotetext{
${ }^{42}$ State specific examples regarding the use of these funds come from either our survey, state Annual Progress and Service Reports to HHS, or our site visits.

${ }^{43}$ Our review of state Annual Progress and Services Reports to HHS found that states have most frequently used their adoption incentive payments for recruitment, post adoption services and training.

${ }^{44}$ Cornerstone Consulting Group, Inc., A Carrot Among the Sticks: The Adoption Incentive Bonus (Houston, 2001).
} 
Table 13: Main Uses of Adoption Incentive Payments and PSSF Adoption Promotion and Support Services Funds

\begin{tabular}{lrr}
\hline Activity & $\begin{array}{r}\text { Number of states } \\
\text { using adoption } \\
\text { incentive payments } \\
\text { (FY 1999 and FY 2000) }\end{array}$ & $\begin{array}{r}\text { Number of states } \\
\text { using PSSF adoption } \\
\text { promotion and support } \\
\text { services funds } \\
\text { (FY 2000) }\end{array}$ \\
\hline Recruitment of adoptive families $^{\mathrm{a}}$ & $19^{\mathrm{a}}$ & $16^{\mathrm{b}}$ \\
\hline Post adoption services $^{\mathrm{c}}$ & $17^{\mathrm{a}}$ & $21^{\mathrm{b}}$ \\
\hline Preadoptive counseling $^{\mathrm{a}}$ & $\mathrm{d}^{\mathrm{a}}$ & 15 \\
\hline $\begin{array}{l}\text { Hiring/Contracting additional } \\
\text { social work staff }\end{array}$ & $13^{\mathrm{e}}$ & 4 \\
\hline Training & 11 & ${ }^{\mathrm{d}}$ \\
\hline
\end{tabular}

Note: Of the 46 states that responded to our survey, 34 provided data on the use of FY 1999 and FY 2000 incentive payments and 26 provided information on the use of FY 2000 PSSF funds.

a One state provided data for CY 1999.

${ }^{\mathrm{b}}$ One state provided data for CY 2000.

${ }^{\mathrm{c}}$ Post adoption services include: counseling, respite care (short-term specialized child care to provide families with temporary relief from the challenges of caring for adoptive children), support groups, adoption subsidies, and adoption preservation services.

${ }^{\mathrm{d}}$ This activity was not included as a response for this funding source.

e One state provided data for SFY 1999 and SFY 2000.

Source: GAO survey.

General recruitment efforts being funded by states include: promoting adoption through National Adoption Month events, hiring additional recruiters, and partnering with religious groups. For example, Maryland has used its PSSF funds to partner with faith-based organizations to recruit adoptive families primarily for black children, while Colorado used its incentive payments to hire a public relations firm to develop a campaign to recruit minority parents. According to our survey results, 18 states are using PSSF funds to create or expand both child specific recruitment efforts and general recruitment programs. ${ }^{45}$

States are also investing adoption incentive payments and PSSF funds in services to help adoptive parents meet the challenges of caring for children who have experienced abuse and neglect. Adoptive parents

\footnotetext{
${ }^{45}$ Of the 46 states that responded to our survey, 34 provided data on new and expanded services funded by PSSF adoption promotion and support services dollars. The 18 states creating or expanding child specific recruitment efforts are not the same 18 states that are creating or expanding general recruitment programs.
} 
sometimes have difficulties managing the emotional and behavioral problems of children from foster care.$^{46}$ Some researchers believe that post adoption services may help stabilize these adoptive families ${ }^{47}$ However, available research on post adoption services is largely descriptive, with little information on the effectiveness of such services. ${ }^{48}$ During our site visits, officials in Massachusetts and Illinois pointed out that the population of adopted children had increased significantly in recent years and that the availability of post adoption services was essential to ensure that these placements remain stable.

Approximately 60 percent of the states responding to our survey used their adoption incentive payments or their PSSF funds or both for post adoption services. Our survey results show that 21 states used PSSF dollars to initiate or expand post adoption counseling and support groups. ${ }^{49}$ In addition, 20 states reported using PSSF dollars to create or expand services to preserve adoptions and help adoptive families maintain their new relationships. Thirteen states also reported that they are providing respite services with PSSF adoption promotion and support services dollars. In addition to these core post adoption services, some states noted both in our survey and in other reports that they are providing a range of other services to adoptive families, including information and referral networks, mentoring, and recreational opportunities. For example, California has used some of its adoption incentive funds to pay for therapeutic camps and tutoring sessions for adopted children. In addition, Minnesota has used PSSF funds to teach adoptive parents how to care for children with fetal alcohol syndrome and children who find it difficult to become emotionally attached to caregivers.

${ }^{46}$ Elizabeth Oppenheim, Shari Gruber, and Doyle Evans, Report on Post-Adoption Services in the States (Washington, D.C.: The Association of Administrators of the Interstate Compact on Adoption and Medical Assistance, Inc., 2000).

${ }^{47}$ Richard P. Barth and others, "Contributors to Disruption and Dissolution of Older-Child Adoption," Child Welfare, vol. LXV, no. 4 (1986).

${ }^{48}$ Richard P. Barth, Deborah A. Gibbs, and Kristin Siebenaler, Assessing the Field of PostAdoption Services: Family Needs, Program Models, and Evaluation Issues (Washington, D.C.: April 10, 2001), http://aspe.hhs.gov/hsp/PASS/lit-rev-01.htm (downloaded Feb. 11, 2002).

${ }^{49}$ The 21 states using PSSF dollars to initiate or expand post adoption counseling are not the same 21 states using PSSF dollars to initiate or expand post adoption support groups. 
Although the 46 states responding to our survey reported that they are most frequently using the money for the activities described above, over two-thirds of them also reported that they are investing some of these funds in other services. ${ }^{50}$ Many states are using PSSF funds to provide preadoptive counseling to help children and parents prepare for the emotional challenges of forming a new family. Similarly, some states are using incentive payments and PSSF funds to train foster families, adoptive families, and service providers. For example, Arkansas used incentive money to help families attend an adoptive parent conference and Nevada used PSSF dollars to fund an adoption-training curriculum in Spanish. Likewise, Montana used incentive payments to provide adoption training to therapists who agree to provide services to children in foster care. Kentucky, on the other hand, has used incentive funds to train judges and attorneys on adoption matters.

In addition, we found that some states are taking advantage of the flexibility allowed in the use of adoption incentive payments to increase the number of people working on child welfare cases. During our site visit to Oregon, child welfare officials told us that the lack of legal resources has inhibited the state's ability to quickly pursue court cases against birth parents to terminate their parental rights and thereby free a child for adoption. To address this issue, Oregon has used its adoption incentive payments to contract for additional lawyers to litigate these cases. According to our survey results, 6 states have used the incentive payments to hire or contract additional legal staff and 13 states have used these funds to hire or contract additional social workers. ${ }^{51}$ Noting that state adoption numbers may level off in the future, a recent report questioned the sustainability of investments made with adoption incentive payments. ${ }^{52}$ Similarly, three states we visited told us that they did not believe they would continue to increase adoption levels and would therefore not earn future incentive payments, and one of these states had limited its use of incentive funds to one time, nonrecurring expenses.

\footnotetext{
${ }^{50}$ Of the 46 states that responded to our survey, 33 reported using their adoption incentive payments or PSSF adoption promotion and support services funds for services other than recruitment or post adoption services. One of these states provided CY data for its use of adoption incentive payments and PSSF adoption promotion and support services funds and one state provided SFY data.

${ }^{51}$ Of the 46 states that responded to our survey, 34 provided data on the use of FY 1999 and FY 2000 adoption incentive payments. One state that reported using incentive payments to hire or contract additional legal staff and social workers provided SFY data.

${ }^{52}$ Cornerstone Consulting Group, Inc., A Carrot Among the Sticks.
} 
States Develop Practices in Response to Long-Standing Barriers That Continue to Hamper Efforts to Promote Permanency for Foster Children
States have been developing a range of practices to address long-standing barriers to achieving permanency for children in a timely manner-many of which have been the subject of our previous reports. Both independently and through demonstration waivers approved by HHS, ${ }^{53}$ states are using a variety of practices to address barriers relating to the courts, recruiting adoptive families for children with special needs, placing children in permanent homes in other jurisdictions, and the availability of needed services. For example, with a demonstration waiver, Maryland is testing whether the provision of comprehensive and coordinated drug treatment services to parents will improve their access to services and reduce the length of time their children spend in foster care. Because few of these practices have been rigorously evaluated, however, limited information is available on their effectiveness.

\section{Systemic Court Problems \\ Continue to Delay Child Welfare Cases}

Our previous work, all the states we visited, and over half of our survey respondents identified problems with the court system as a barrier to moving children from foster care into safe and permanent homes. For example, 29 states reported in our survey that the child welfare system did not have enough judges or court staff, 28 reported that not enough training was available for judges or other court personnel, and 23 reported the existence of judges who were not supportive of ASFA's goals. ${ }^{54}$ In 1999, we reported on systemic problems that hinder the ability of courts to produce decisions on child welfare cases in a timely manner that meet the needs of children. ${ }^{55}$ The barriers included inadequate numbers of judges and attorneys to handle large caseloads, the lack of cooperation between the courts and child welfare agencies, and insufficient training of judges and attorneys involved in child welfare cases.

\footnotetext{
${ }^{53}$ See appendix II for a description of current waiver projects and the status of their evaluations.

${ }^{54}$ Of the 46 states that responded to our survey, 40 reported on the insufficient number of judges and court staff, 41 reported on the lack of training for judges and court staff, and 39 reported on judges not being supportive of ASFA's goals. Of the 29 states that reported an insufficient number of judges or court staff, 18 reported that the problem represented a moderate, great, or very great hindrance to finding permanent homes for children. Of the 28 states that reported insufficient training for court staff, 20 reported that the problem represented a moderate or great hindrance. Of the 23 states that reported that judges were not supportive of ASFA's goals, 10 reported that the problem represented a moderate, great, or very great hindrance.

${ }^{55}$ U.S. General Accounting Office, Juvenile Courts: Reforms Aim to Better Serve Maltreated Children, GAO/HEHS-99-13 (Washington, D.C.: Jan. 11, 1999).
} 
During our visit to Massachusetts, state officials told us that the courts experienced significant delays in court hearings and appeals due to a lack of court resources. As an alternative to court proceedings, Massachusetts implemented a permanency mediation program - a formal dispute resolution process in which an independent third party facilitates permanency planning between family members and potential adoptive parents in a nonadversarial setting. Three other states we visited-Texas, Oregon, and Maryland-have implemented similar mediation programs. By avoiding trials to terminate parental rights, Massachusetts officials reported that permanency mediation helps reduce court workloads and more effectively uses limited court resources. In addition, they told us that the mediation process eliminates appeals because a joint permanency decision is made between the birth parents and the adoptive parents that both parties can accept. For example, an open adoption between the birth and adoptive parents is a common outcome of permanency mediation, allowing the birth parents to continue some type of relationship with their child after adoption. A preliminary evaluation of the Massachusetts program suggested that cases involved in the mediation program needed less time and fewer court resources to reach an agreement than cases that go to trial. However, the evaluation did not directly compare outcomes, such as the length of time a child spent in foster care, for mediation and nonmediation cases.

To improve collaboration between child welfare and court staff, two states we visited developed ongoing committees to address barriers to achieving permanency for children in foster care. For example, Massachusetts created a committee comprised of staff from the courts, the Attorney General's office, and the child welfare agency to identify and address court delays affecting child welfare cases. This committee has studied delays in the process for appealing child welfare decisions and has implemented several changes to streamline the process. Illinois has several ongoing committees composed of court and child welfare agency staff to address a variety of legal barriers that delay the placement of a child in a safe and permanent home.

Texas officials identified court barriers in rural areas that negatively affect both the timeliness and quality of child welfare proceedings-specifically, the lack of court time for child welfare cases and the lack of judges with training and experience in child welfare issues. In response to these barriers, Texas developed the visiting judge cluster court system, an approach in which a judge trained in child welfare issues is assigned to a cluster of rural counties. The judge travels from county to county presiding over all child welfare cases. This approach can create more 
court time in rural areas and allows knowledgeable and experienced judges to make the best possible decisions for children in foster care. While Texas officials believe this approach has been helpful in moving children to permanency, no formal evaluation of the approach has been conducted.

\section{Permanency for Children with Special Needs Hindered by Lack of Adoptive Families}

Officials in five states we visited, along with the majority of the respondents to our state survey, reported that difficulties in recruiting families to adopt children with special needs is a major barrier to achieving permanent placements for these children. ${ }^{56}$ The National Center for Resource Family Support notes that the lack of foster and adoptive families to meet the needs of children in care is one of the biggest challenges facing child welfare agencies across the nation. ${ }^{57}$ In Texas and Illinois, social work staff and state officials noted that the children currently in foster care are older and have more severe problems, making it increasingly difficult in find adoptive homes for the children in care.

Our survey revealed that states relied on three main activities to recruit adoptive families for children who are waiting to be adopted: listing a child's profile on state and local Web sites, exploring adoption by adults significantly involved in the child's life, and featuring the child on local television news shows. ${ }^{58}$ Other recruitment efforts cited by the states we visited included profiling children in need of adoptive families in local newspapers, holding regular meetings during which social workers across the state exchange information on children in their communities who need an adoptive family and local families available to adopt, and holding adoption parties during which children available for adoption are introduced to families who are waiting to adopt a child. In Massachusetts, the child welfare agency established a successful collaboration with a local company that sponsored adoption fairs for children with special needs, donated space for meetings, and provided advice on effective

\footnotetext{
${ }^{56}$ Of the 46 states responding to our survey, 43 states reported on the sufficiency of adoptive homes for children with special needs. All 43 states reported that they did not have enough adoptive homes for children with special needs, with 39 reporting that the problem represented a moderate, great, or very great hindrance to finding permanent homes for children.

${ }^{57}$ National Center For Resource Family Support, Casey Family Programs, http://www.casey.org/cnc/recruitment/index.htm (downloaded Apr. 9, 2002).

${ }^{58}$ Of the 46 states responding to our survey, 44 provided information on recruitment activities used in their states.
} 
marketing techniques. In Illinois and Maryland, staff use databases to match children with a goal of adoption with families waiting to adopt a child.

Several states we visited are also using recruitment campaigns targeted to particular individuals who may be more likely to adopt children with special needs. However, a report on recruitment efforts in Illinois noted that little information exists on what kinds of families are likely to adopt children with specific characteristics. ${ }^{59}$ The child welfare agencies in Maryland, North Carolina, Texas, and Illinois are collaborating with local churches to recruit adoptive families specifically for minority children. In addition, Illinois conducted a recruitment campaign at local hospitals to identify adoptive families for children with complex medical needs; however, of the 14 children adopted as a result of the campaign, only one had a complex medical need. While the states we visited used a variety of recruitment efforts to find families for special needs children, they generally did not collect data on the effectiveness of their recruiting efforts.

During our site visit, Illinois social workers discussed the importance of consulting with people involved in a child's life, such as coaches and teachers, to identify those who might be interested in adopting a child. However, the Illinois recruitment report found that many adoption workers did not have the experience or skills to carry out such childspecific recruitment activities effectively. To address this, the state has established a training program for social workers on specialized recruitment activities.

ASFA requires states to document the individualized recruitment efforts undertaken for a child waiting for an adoptive family. The states we visited used several documentation methods, such as making notes in a child's case record, using tracking forms, and using computerized databases that document all actions taken on a child's case. For example, state officials in Oregon recently created a new document that social workers must use to record efforts made to recruit adoptive families for foster children. In Massachusetts, if a child has a goal of adoption and no identified adoptive family, the social worker is required to submit an electronic referral form within a specified timeframe to the regional recruitment office.

\footnotetext{
${ }^{59}$ Jane Elmore and Diane DeLeonardo, Report on the Status Of Foster and Adoptive Parent Recruitment In the Illinois Child Welfare System (Springfield, Ill.: n.p., 2002).
} 
In addition to the activities described above, some demonstration waivers are testing different approaches to finding permanent homes for children in foster care. Seven states are using demonstration waivers to pay subsidies to relatives and foster parents who become legal guardians to foster children in their care. These states hope to reduce the number of children in long-term foster care by formalizing existing relationships in which relatives or foster parents are committed to caring for a child but adoption is not a viable option. For example, older children may not consent to an adoption because they still have a relationship with their parents who are unable to care for them. In other cases, a grandmother may be committed to caring for her grandchildren, but may not want to be involved in terminating the parental rights of her child. Evaluation results from Illinois's waiver suggest that offering subsidized guardianship can increase the percentage of children placed in a permanent and safe home. Results from most of the other guardianship waiver projects are not yet available.

Texas is using a waiver to test a new strategy for placing children in adoptive homes, with a goal of recruiting more prospective adoptive families and increasing the percentage of children with a filed or approved TPR that are placed in adoptive families. Texas hopes to better match children and families and improve the stability of these placements by providing training for potential adoptive families and having mental health professionals assess the child's readiness to bond with a family and the family's ability to meet the emotional needs of the child. This project was implemented in 2001 and preliminary evaluation results are expected by the end of 2003.

Placing Children Across Jurisdictions Remains Problematic for States
Many states encounter long-standing barriers in placing children with adoptive families in other states and across jurisdictions within the same state. As we reported previously, these interjurisdictional adoptions take longer and are more complex than adoptions within the same child welfare jurisdiction. ${ }^{60}$ Interjurisdictional adoptions involve recruiting adoptive families from other states or other counties within a state, conducting comprehensive home studies of adoptive families in one jurisdiction, sending the resulting home study reports to another jurisdiction, and ensuring that all required legal, financial, and administrative processes for interjurisdictional adoptions are completed.

${ }^{60}$ U.S. General Accounting Office, Foster Care: HHS Could Better Facilitate the Interjurisdictional Adoption Process, GAO/HEHS-00-12 (Washington, D.C.: Nov. 19, 1999). 
Five states we visited reported frequent delays in obtaining from other states the home study reports necessary to place a child with a potential adoptive family in another state. According to recent HHS data, children adopted by out-of-state families typically spend about 1 year longer in foster care than children adopted by in-state families.

Child welfare agencies have implemented a range of practices to facilitate adoptions across state and county lines. In our survey, the most common practices for recruiting adoptive families in other jurisdictions in fiscal year 2000 included publicizing profiles of foster children on Web sites, presenting profiles of children in out-of-state media, and contracting with private agencies to recruit adoptive parents in other states. ${ }^{61}$ The majority of states using these strategies rated them as very or somewhat effective. States have also developed practices to expedite the completion of home studies and shorten the approval processes for interstate adoptions. The two primary practices cited by states on our survey were working with neighboring states to facilitate interstate placements and contracting with private agencies to conduct home studies in other states. ${ }^{62}$ Other practices cited by a smaller number of states include increasing the number of staff to work on and approve interstate placements, using home study forms similar to the ones used in other states, and developing agreements with other states to allow social workers to perform home studies across state lines. ${ }^{63}$ In rating these practices, states reported in our survey that increasing the number of staff was the most successful strategy and using common home study forms was the least effective solution.

\footnotetext{
${ }^{61}$ Of the 46 states that responded to our survey, 22 reported that they publicized profiles of foster children in media in other states, (20 reported FY data, 1 reported CY data, and 1 reported SFY data). Forty-one states reported that they publicized profiles of foster children on web sites (37 reported FY data, 2 reported $\mathrm{CY}$ data, and 2 reported SFY data). Fifteen states reported that they contracted with private agencies to recruit adoptive parents in other states (13 reported FY data, 1 reported CY data, and 1 reported SFY data).

${ }^{62}$ Of the 46 states responding to our survey, 35 reported that they worked with neighboring states to facilitate interstate placements (31 reported FY data, 2 reported CY data, and 2 reported SFY data). Nineteen states reported that they contracted with private agencies in other states to conduct home studies (16 reported FY data, 2 reported CY data, and 1 reported SFY data).

${ }^{63}$ Of the 46 states responding to our survey, 9 states reported increasing the number of staff to approve interstate placements and 5 reported establishing agreements with other states to allow social workers to conduct home studies across state lines. Nine states also reported using common home study forms (8 reported FY data and 1 reported SFY data).
} 
States we visited have implemented several of these practices to overcome barriers to interjurisdictional adoptions. In Oregon, the state child welfare agency works with neighboring states in the Northwest Adoption Exchange to recruit adoptive parents for children with special needs. In Texas, the state contracts with private agencies to place foster children with out-of-state adoptive families. In Illinois, the state works with a private agency in Mississippi to conduct home studies because many Illinois children are adopted by families in Mississippi.

\section{Poor Access to Services Can Impede Permanency Decisions}

Officials in four states told us that making decisions about a child's permanent home within a year is difficult if the parent has not had access to the services necessary to address their problems, particularly substance abuse treatment. We have previously reported on barriers to working with parents who have a substance abuse problem, including inadequate treatment resources and a lack of collaboration among substance abuse treatment providers and child welfare agencies. ${ }^{64}$ Similarly, 33 states reported in our survey that the lack of substance abuse treatment programs is a barrier to achieving permanency for children. ${ }^{65}$

To address this issue, four states have developed waiver projects to address the needs of parents with substance abuse problems. By testing ways to engage parents in treatment and to provide more supportive services, these states hope to increase the number of substance abusing parents who engage in treatment, increase the percentage of children who reunify with parents who are recovering from a substance abuse problem, and reduce the time these children spend in foster care. For example, Delaware's waiver funds substance abuse counselors to help social workers assess potential substance abuse problems and engage parents in treatment. The final evaluation report, published in March 2002, concluded that while the project did not achieve many of its intended outcomes, one-third of families in the project were effectively linked to substance abuse treatment, foster children in the project spent 14 percent less time in foster care than similar non-waiver children, and total foster

\footnotetext{
${ }^{64}$ U.S. General Accounting Office, Foster Care: Agencies Face Challenges Securing Stable Homes for Children of Substance Abusers, GAO/HEHS-98-182 (Washington, D.C.: Sept. 30, 1998).

${ }^{65}$ Of the 46 states that responded to our survey, 39 reported on the lack of substance abuse treatment programs. Of the 33 states that reported that not enough drug treatment programs were available, 26 reported that the problem represented either a moderate, great, or very great hindrance to finding permanent homes for children.
} 
care costs were reduced. Interim evaluation results for two of the other states are expected by the end of 2002. The fourth state will not have interim results until 2004 .

Two states we visited are working to improve access to services and collaboration among service providers through a collaborative approach called family group conferencing. ${ }^{66}$ Oregon law requires the child welfare agency to consider holding a family conference within the first 30 days a child is in care. ${ }^{67}$ At these meetings, parents, relatives, child welfare agency staff, and other professionals, such as therapists, work together to develop appropriate plans that address the child's need for safety and permanency and to ensure that the family has access to services needed to implement the permanency plan. North Carolina uses similar meetings for children who are at risk of being placed in foster care, during which the child's birth family, relatives, and other involved adults develop plans for protecting the child, which must be approved by the child welfare agency. In both states, the goal of these meetings is to empower families to participate in the planning process for their children and to foster cooperation and communication between families and the child welfare professionals. While North Carolina officials believe the family conferences have been useful, little data exists to demonstrate whether children who are the subjects of these meetings have better outcomes than other children in the child welfare system. ${ }^{68}$ Several states, including North Carolina, have incorporated family group conferencing into their waiver projects and may produce some information on the effectiveness of this approach.

\section{Conclusions}

Most of the states we visited reported that ASFA has played an important role in helping them focus on achieving permanency for children within the first year that they enter foster care. However, numerous problems with existing data make it difficult to assess at this time how outcomes for

\footnotetext{
${ }^{66}$ Family group conferencing is known by a variety of names, such as family decision meeting and family decision-making conferences, but encompass similar goals and approaches.

${ }^{67}$ If the agency determines that such a conference is appropriate, it must be held, whenever possible, before the child has been in care for 60 days.

${ }^{68}$ Lisa Merkel-Holguin, What is FGDM?, (East Englewood, Colo.: National Center on Family Group Decision Making, American Humane Association, 2001), http://www.ahafgdm.org/what_is.htm.
} 
children in foster care have changed since ASFA was enacted. While an increasing number of children have been placed in permanent homes through adoption during the last several years, we know little about the role ASFA played in the adoption increases or other important outcomes, such as whether children who reunify with their families are more or less likely to return to foster care or whether these adoptions are more or less stable than adoptions from previous years.

The availability of reliable data, both on foster care outcomes and the effectiveness of child welfare practices, is essential to efforts to improve the child welfare system. In the past few years, HHS and the states have taken important steps to improve the data available to assess child welfare operations. In addition, evaluation data from the demonstration waivers should be available in the next few years, providing key information on child welfare practices that are effective and replicable. However, important information about ASFA's impact on children in foster care is still unavailable. For example, the lack of comprehensive and consistent data regarding the fast track and 15 of 22 provisions make it difficult to understand the role of these new provisions in reforming the child welfare system and moving children into permanent placements.

Recommendation to the Secretary of Health and Human Services
To obtain a clearer understanding of how ASFA's two key permanency provisions are working, we recommend that the Secretary review the feasibility of collecting data in the most cost-effective way on states' use of ASFA's fast track and 15 of 22 provisions. Information, such as the number of children exempted from the 15 of 22 provision and the reasons for the exemptions, could help HHS better target its limited resources to key areas where the states may need assistance in achieving ASFA's goals. Health and Human Services' Administration for Children and Families (ACF). These comments are reproduced in appendix III. ACF also provided technical clarifications, which we incorporated when appropriate.

ACF generally agreed with the findings of our report, pointing out the difficulty in understanding ASFA's effect on child welfare outcomes, given that many states had implemented child welfare reforms prior to ASFA and that some states implemented ASFA more quickly than others. ACF also said that states continue to revise AFCARS data for early as well as for recent years, thereby improving the accuracy of the information. 
ACF concurred with our recommendation and reported that it has established a team to review AFCARS data issues. This team plans to evaluate the feasibility of including data on ASFA's fast track and 15 of 22 provisions in the AFCARS system. ACF also noted that states are required to report the number of terminations of parental rights and use of exceptions in the statewide assessment portion of their CFSR. However, the statewide assessment form states are required to complete prior to the CFSR does not request data on the number of TPRs filed and does not specifically request data on the state's use of the 15 of 22 provision. Instead, it asks states to discuss the extent to which the state complies with the 15 of 22 provision. Four of the states we visited had undergone a CFSR prior to our site visit and we reviewed the statewide assessment forms they submitted to HHS. Two states provided some data on their use of the 15 of 22 provision in their statewide assessment and two states did not. In addition, few states were able to provide this data in response to our survey, including states that have undergone a CFSR.

We also provided a copy of our draft to child welfare officials in the six states we visited (Illinois, Maryland, Massachusetts, North Carolina, Oregon, and Texas). Illinois, Maryland, and Texas generally agreed that the draft accurately portrayed the experiences of their states. Oregon and North Carolina provided a few technical comments to clarify information presented about their states, which we incorporated when appropriate. In addition, Oregon determined that it had submitted inaccurate data for a survey question that appeared in a table in the report. We revised the table based on its corrected data submission. Massachusetts did not provide any comments.

We are sending copies of this report to the Secretary of Health and Human Services, state child welfare directors, and other interested parties. We will make copies available to others on request. If you or your staff have any questions or wish to discuss this material further, please call me at (202) 512-8403 or Diana Pietrowiak at (202) 512-6239. Key contributors to this report are listed in appendix IV.

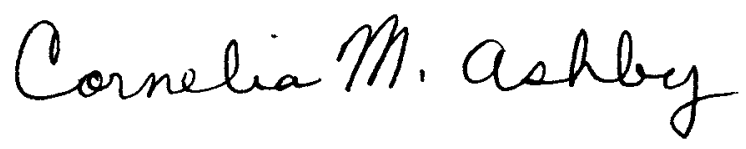

Cornelia M. Ashby

Director, Education, Workforce, and Income Security Issues 


\section{Appendix I: Scope and Methodology}

To determine how the characteristics of children in foster care and their outcomes, such as adoption, have changed since ASFA was enacted, we reviewed national child welfare data sets and statistical reports.

Specifically, we examined data from HHS's Adoption and Foster Care Analysis and Reporting System (AFCARS) for federal fiscal years 1998, 1999, and 2000. To understand these data in a historical context, we reviewed early child welfare data from the Voluntary Cooperative Information System (VCIS) administered by the American Public Human Services Association (formerly known as the American Public Welfare Association). In addition, we reviewed longitudinal analyses of child welfare trends from the Chapin Hall Center for Children at the University of Chicago.

To gauge how useful states have found ASFA's fast track and 15 of 22 provisions, as well as to explore foster care outcomes in greater detail, we surveyed all 50 states and the District of Columbia. We pretested the survey instrument in Delaware and Vermont and received input from HHS officials. In November 2001, we sent a copy of the survey to the child welfare director in each of the 50 states and the District of Columbia. We received responses from 45 state agencies and the District of Columbia. While we requested survey data for federal fiscal years 1999 and 2000, in some cases, states provided data for alternative timeframes. Twenty-four states reported data by federal fiscal year; 2 states reported data by calendar year; and 20 states used a combination of reporting periods, including federal fiscal year, state fiscal year, and calendar year. We did not independently verify the information obtained through the survey. In addition, we visited 6 states to obtain more detailed and qualitative information regarding ASFA's effect on state child welfare agencies. We conducted site visits in Illinois, Maryland, Massachusetts, North Carolina, Oregon, and Texas. We selected these states to represent a range of geographic locations, performance under the adoption incentive program, and child welfare system innovations. During our site visits, we interviewed state and local child welfare staff, nonprofit service providers, and judges. We also collected and reviewed relevant documentation from these site visits.

To determine how states are spending new adoption-related funds provided by ASFA, we included questions on this issue in our national survey. We also reviewed descriptions of adoption incentive payment and PSSF adoption promotion and support services fund expenditures in excerpts of the Annual Progress and Services Reports states submitted to the Children's Bureau in June 2001. As a supplement to these reports, we gathered information on the use of these funds from regional ACF 
contacts and during our site visits. In addition, we reviewed related reports from the Cornerstone Consulting Group, Inc. and James Bell Associates. ${ }^{1}$

To identify what states are doing to address barriers to achieving permanency, we interviewed HHS officials and child welfare experts, as well as addressed this issue in our national survey and 6 site visits. The child welfare experts we spoke with included individuals from the Child Welfare League of America, the National Adoption Center, the American Public Human Services Association, the Dave Thomas Foundation for Adoption, the Urban Institute, the Center for Law and Social Policy, and the Association of Administrators of the Interstate Compact on the Placement of Children. We also reviewed relevant child welfare reports, such as the National Governor's Association report on best practices and the Cornerstone Consulting Group, Inc.'s report on HHS's child welfare waivers. $^{2}$

We conducted our work between June 2001 and April 2002 in accordance with generally accepted government auditing standards.

${ }^{1}$ Cornerstone Consulting Group, Inc., A Carrot Among the Sticks and James Bell Associates, Analysis of States' Annual Progress and Services Reports.

${ }^{2}$ National Governors' Association Center for Best Practices, A Place to Call Home: State Efforts to Increase Adoptions and Improve Foster Care Placements (Washington, D.C., 2000). Cornerstone Consulting Group, Inc., Child Welfare Waivers: Promising Directions, Missed Opportunities (Houston, 1999) 


\section{Appendix II: Summary of Child Welfare Demonstration Waivers}

Eighteen states are currently using Title IV-E demonstration waivers to test child welfare innovations, such as providing extensive post adoption services to encourage adoptions and maintain their stability. However, most of the evaluation results from the current waivers are not yet available. The first waivers were approved in 1996, but the waiver projects last for 5 years and many of them were not implemented until 1999 or later. An HHS official also told us that some of the waivers experienced unexpected difficulties and took longer to implement than expected. As a result, about half of the waiver projects have not yet submitted interim evaluation results. In addition, some of the waiver projects have enrolled fewer participants than expected, which has delayed the availability of conclusive evaluation results. Final evaluation results for the first three waiver projects approved are expected to be published this year (see table 14 for a list of waiver projects and when their evaluations are expected). According to an HHS official, subsidized guardianship is the only waiver practice that has sufficient evidence thus far to warrant the consideration of policy changes to support the broader use of this practice. While some other waivers may have promising preliminary results, none are strong enough to warrant a change in policy at this time. 


\begin{tabular}{|c|c|c|c|c|c|}
\hline Project & State $^{a}$ & $\begin{array}{r}\text { Date waiver was } \\
\text { approved }\end{array}$ & $\begin{array}{r}\text { Date waiver was } \\
\text { implemented }\end{array}$ & $\begin{array}{r}\text { Interim evaluation } \\
\text { expected } / \\
\text { submitted }\end{array}$ & $\begin{array}{r}\text { Final evaluation } \\
\text { expected/ } \\
\text { submitted }\end{array}$ \\
\hline \multirow{8}{*}{$\begin{array}{l}\text { Subsidized } \\
\text { guardianship }\end{array}$} & Delaware & June 1996 & July 1996 & June 1999 & Apr. 2002 \\
\hline & Illinois & Sept. 1996 & May 1997 & Dec. 1999 & Nov. 2002 \\
\hline & Maryland & Apr. 1997 & Feb. 1998 & Dec. 2000 & June. 2003 \\
\hline & Montana & Sept. 1998 & June 2001 & Dec. 2003 & Mar. 2007 \\
\hline & New Mexico ${ }^{b}$ & June 1999 & July 2000 & Dec. 2002 & Dec. 2005 \\
\hline & New Mexico $^{c}$ & June 1999 & Apr. 2001 & Apr. 2003 & Apr. 2006 \\
\hline & North Carolina & Nov. 1996 & July 1997 & June 2000 & Dec. 2002 \\
\hline & Oregon & Oct. 1996 & July 1997 & July 2000 & Mar. 2003 \\
\hline \multirow[t]{5}{*}{ Managed care } & Colorado & Sept. 1999 & Oct. 2001 & Mar. 2004 & Mar. 2007 \\
\hline & Connecticut & Sept. 1998 & July 1999 & Mar. 2002 & Mar. 2004 \\
\hline & Maryland & Sept. 1999 & Jan. 2000 & July 2002 & June 2005 \\
\hline & Michigan & Dec. 1997 & Oct. 1999 & Sept. 2002 & June 2005 \\
\hline & Washington & Sept. 1998 & Mar. 2002 & Sept. 2004 & Sept. 2007 \\
\hline \multirow[t]{4}{*}{ Substance abuse } & Delaware & June 1996 & July 1996 & June 1999 & Apr. 2002 \\
\hline & Illinois & Sept. 1999 & Apr. 2000 & Dec. 2002 & Dec. 2005 \\
\hline & Maryland & Sept. 1999 & Oct. 2001 & Mar. 2004 & Mar. 2007 \\
\hline & New Hampshire & Sept. 1998 & Nov. 1999 & Oct. 2002 & July 2005 \\
\hline \multirow{4}{*}{$\begin{array}{l}\text { Capped IV-E } \\
\text { allocation and } \\
\text { flexibility }\end{array}$} & Indiana & July 1997 & Jan. 1998 & Feb. 2001 & Apr. 2003 \\
\hline & North Carolina & Nov. 1996 & July 1997 & June 2000 & Dec. 2002 \\
\hline & Ohio & Feb. 1997 & Oct. 1997 & Nov. 2000 & July 2003 \\
\hline & Oregon & Oct. 1996 & July 1997 & July 2000 & Mar. 2003 \\
\hline \multicolumn{6}{|l|}{ Other } \\
\hline \multirow[t]{2}{*}{ Intensive services } & California & Aug. 1997 & Dec. 1998 & Jan. 2002 & Mar. 2004 \\
\hline & Mississippi & Sept. 1998 & Apr. 2001 & Mar. 2004 & Sept. 2006 \\
\hline Training & Illinois & Aug. 2001 & Aug. 2002 & Dec. 2004 & Feb. 2008 \\
\hline $\begin{array}{l}\text { Post adoption } \\
\text { services }\end{array}$ & Maine & Sept. 1998 & Apr. 1999 & Feb. 2002 & Jan. 2005 \\
\hline Tribal administration & New Mexico & June 1999 & July 2000 & Dec. 2002 & Dec. 2005 \\
\hline $\begin{array}{l}\text { Adoption recruitment } \\
\text { and matching }\end{array}$ & Texas & Sept. 1999 & July 2001 & Dec. 2003 & Jan. 2006 \\
\hline
\end{tabular}

Note: Key dates are subject to change.

${ }^{a}$ Some states have multiple waivers. In addition, some approved waivers have more than one component. For example, Maryland's second waiver has two components-a managed care project and a substance abuse project-that have different implementation dates.

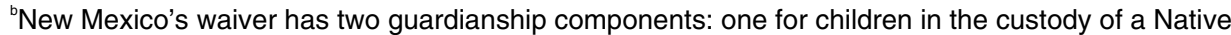
American tribe and one for children in state custody. This is the tribal guardianship component.

'New Mexico's waiver has two guardianship components: one for children in the custody of a Native American tribe and one for children in state custody. This is the state custody guardianship component.

Source: Profiles of Child Welfare Waiver Demonstration Projects, James Bell Associates, February 2002; and additional data provided by James Bell Associates. 
The waivers currently underway focus primarily on four practice areas: subsidized guardianship, managed care approaches, services for substance abusing parents, and the flexible use of Title IV-E funds. Seven states are using waivers to pay subsidies to relatives and foster parents who become legal guardians to foster children in their care. These states hope to reduce the number of children in long-term foster care by formalizing existing relationships in which relatives or foster parents are committed to caring for a child but adoption is not a viable option. This option is considered useful particularly for older children and children placed with relatives. Results from Illinois's waiver suggest that offering subsidized guardianship can increase the percentage of children placed in a permanent and safe home without reducing the number of children being adopted. Results from most of the other guardianship waiver projects are not available either because the project just started or because too few children have participated in the waiver project thus far.

Five states are testing managed care approaches for financing child welfare services. Under these waivers, states and localities prospectively pay fixed amounts to providers to coordinate and meet all the service needs of referred children. For example, Connecticut is using a managed care approach for children between the ages of 7 and 15 with severe behavioral and mental health problems. The state pays a fixed fee to agencies to provide and coordinate services for referred children with the goal of placing them in the least restrictive setting and reducing the time they spend in foster care. Preliminary findings from a 1-year period indicate that children in the waiver project were less likely to be placed in restrictive foster care settings and psychiatric hospitals, compared to similar children who were not in the waiver project. Results from the other managed care projects are not yet available, primarily because the projects were only recently implemented.

Four states developed waiver projects to address the needs of parents with substance abuse problems. Using these waivers, the states hope to increase the number of substance abusing parents who engage in treatment, increase the percentage of children who reunify with parents who are recovering from a substance abuse problem, and reduce the time these children spend in foster care. For example, Delaware has used Title IV-E funds to pay for a substance abuse counselor to accompany social workers who investigate allegations of abuse or neglect. The substance abuse counselor assists in assessing potential substance abuse problems and engaging parents in treatment. Final evaluation results were published in March 2002 and concluded that the project successfully engaged parents in substance abuse treatment and resulted in foster care cost 
savings, although it did not achieve many of its intended outcomes. For example, children participating in the waiver project spent 14 percent less time in foster care than similar children who were not part of the waiver project, although the project's goal was a 50 percent reduction. Interim evaluation results for two of the other states are expected by the end of 2002. The fourth state will not have interim results until 2004.

Four states have designed waiver projects allowing counties or other local entities to use Title IV-E funds more flexibly for prevention and community-based services not traditionally reimbursed by Title IV-E, with the goal of preventing foster care placements and facilitating reunification. These waivers provide counties with a fixed Title IV-E budget and allow them to provide any services that will improve outcomes for children. For example, Indiana counties involved in the waiver provided a variety of services, including in-home family counseling, child care, mentoring, respite services, and financial assistance, such as paying for transportation or utilities. Preliminary results from Indiana indicate that children in waiver counties spent less time in foster care, were more likely to be reunified, and were less likely to re-enter care compared to similar children in nonwaiver counties. In contrast, preliminary analyses from Oregon do not demonstrate any significant differences in reunification rates or the incidence of re-abuse after reunification between children who participated in the waiver program and similar children who did not. In North Carolina, a preliminary report indicates that waiver counties are experiencing a reduction in first time entry into foster care compared to non-waiver counties; however, the report also points out that further analysis is necessary to demonstrate that this outcome is a result of the waiver activities. North Carolina reports that findings on the reduction in length of stay and re-entry into care are inconclusive at this time. 


\section{Appendix III: Comments from the Department of Health and Human Services}

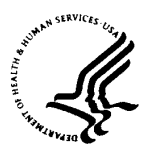

ADMINISTRATION FOR CHILDREN AND FAMILIES

Office of the Assistant Secretary, Suite 600

370 L'Enfant Promenade, S.W.

Washington, D.C. 20447

JUN 132002

TO:

Cornelia M. Ashby, Director

Education, Workforce, and Income Security Issues

United States General Accounting Office

FROM:

Wade F. Horn, Ph.D.

Assistant Secretary

for Children and Families

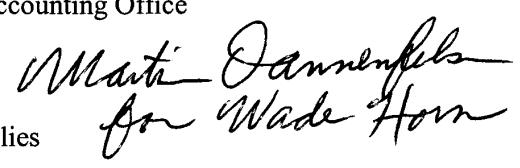

SUBJECT: Comments on the General Accounting Office's Draft Report "Recent

Legislation Helps States Focus on Finding Permanent Homes for Children, but Long-Standing Barriers Remain" (GAO-02-585)

Attached are the Administration for Children and Families' comments on the above report which addresses the impact of legislation to expedite the achievement of permanency for children in foster care.

We appreciate the opportunity to comment on the report. Should you have questions or need additional information, please contact Susan Orr, Associate Commissioner of the Children's Bureau at (202) 205-8618. 


\section{Appendix III: Comments from the Department}

of Health and Human Services

COMMENTS OF THE ADMINSTRATION FOR CHILDREN AND FAMILIES ON THE GENERAL ACCOUNTING OFFICE'S DRAFT REPORT, "RECENT LEGISLATION HELPS STATES FOCUS ON FINDING PERMANENT HOMES FOR CHILDREN, BUT LONGSTANDING BARRIERS REMAIN" (GAO-02-585)

The Administration for Children and Families (ACF), Administration for Children, Youth and Families (ACYF), Children's Bureau (CB) appreciates the opportunity to comment on this draft report which addresses the impact of legislation to expedite the achievement of permanency for children in foster care.

\section{General Comments}

The GAO report on the impact of the Adoption and Safe Families Act (ASFA) provides a thoughtful analysis of data related to State performance since ASFA was passed. States may use this information to evaluate their services to families and children. Since states face many different barriers to the achievement of permanency for children, it is important for individual states to do self-assessments of how the provisions of ASFA could be better implemented. Statespecific assessments are a useful way to understand current practice and to develop effective strategies for improvement.

It should be noted that states continue to revise and re-submit Adoption and Foster Care Analysis and Reporting System data for early as well as recent years, thereby improving the accuracy of information and reducing the amount of missing information. Continued analysis of the more accurate data will provide additional insights into states' performance.

Another point that deserves mentioning is that some of the conclusions in this report are based on the concept that there are defined timeframes that constitute pre-and-post ASFA. Many states made significant progress towards increasing adoptions well before the passage of ASFA. In addition, states implemented the Federal legislation at various rates of speed. Also, some states enacted and implemented similar legislation prior to the passage of ASFA. This increases the difficulty in determining the impact of ASFA, since there was a gradual change in law and procedures rather than a specific change with ASFA's passage.

\section{GAO Recommendation}

To obtain a clearer understanding of how AFSA's two key permanency provisions are working, we recommend that the Secretary review the feasibility of collecting data in the most costeffective way on states' use of ASFA's fast track and 15 of 22 provisions. Information, such as the number of children exempted under the 15 of 22 provision and the reasons for exemptions, could help HHS better target its limited resources to key areas where states may need assistance in achieving ASFA's goals.

ACF Comment

HHS has established a team to review the Adoption and Foster Care Analysis and Reporting System's (AFCARS) data elements and other data issues. The team intends to evaluate the feasibility of including data elements related to: 
Appendix III: Comments from the Department

of Health and Human Services

Page 2

- the termination of parental rights when the courts have determined that the provision of services to the parents is not necessary due to egregious situations, and

- the requirement for documentation of exceptional circumstances when termination of parental rights is not pursued after a child has been in foster care 15 out of 22 months.

The Child and Family Services (CFS) reviews provide an outcomes-based model utilizing multiple sources of information for assessing child protection and child welfare services provided by the states. States are required to report the number of terminations of parental rights and the use of exceptions in the statewide assessment portion of the CFS reviews. These elements are also noted in the CFS reviews during the on-site review of specific cases. Additional information obtained during the CFS reviews gives the context needed to understand if the provisions related to egregious situations and the 15 out of 22 months exceptions are being used appropriately in specific cases. Using the full information gathered in the review allows HHS to better target technical assistance resources to specific barriers in a specific state. Each state will have completed a statewide assessment by October 2004. The CFS reviews help identify strengths the states have to build on and the needs that they should address in program improvement plans. 


\section{Appendix IV: GAO Contacts and Acknowledgments}




\section{Bibliography}

Barth, Richard P., Deborah A. Gibbs, and Kristin Siebenaler. Assessing the Field of Post-Adoption Service: Family Needs, Program Models, and Evaluation Issues. A literature review prepared at the request of the Department of Health and Human Services. April 10, 2001.

Barth, Richard P., and others. "Contributors to Disruption and Dissolution of Older-Child Adoptions.” Child Welfare, vol. LXV, no. 4 (1986): 359-371.

Congressional Research Service. Child Welfare: Implementation of the Adoption and Safe Families Act. Washington, D.C., 2001.

Cornerstone Consulting Group, Inc. A Carrot Among the Sticks: The Adoption Incentive Bonus. Houston, 2001.

Cornerstone Consulting Group, Inc. Child Welfare Waivers: Promising Directions, Missed Opportunities. Houston, 1999.

Elmore, Jane and Diane DeLeonardo. Report on the Status Of Foster and Adoptive Parent Recruitment In the Illinois Child Welfare System. N.p., 2002.

Festinger, Trudy. After Adoption: A Study of Placement Stability and Parents' Service Needs. New York: Shirley M. Ehrenhranz School of Social Work, New York University, 2001.

Goerge, Robert M., and others. Adoption, Disruption, and Displacement in the Child Welfare System, 1976-1995. Chicago: The Chapin Hall Center for Children at the University of Chicago, 1995.

Harden, Allen, Fred Wulczyn, and Robert Goerge. Adoption from Foster Care: The Dynamics of the ASFA Foster Care Population. Chicago: The Chapin Hall Center for Children at the University of Chicago, 1999.

James Bell Associates. Analysis of States' Annual Progress and Services Reports and Child and Family Services Plans (1999-2001). Arlington, Va., 2002.

Maza, Penelope L. "Recent Data on the Number of Adoptions of Foster Children." Adoption Quarterly, vol. 3 (1999): 71-81.

National Governors' Association Center for Best Practices. A Place to Call Home: State Efforts to Increase Adoptions and Improve Foster Care Placements. Washington, D.C., 2000. 
Oppenheim, Elizabeth, Shari Gruber, and Doyle Evans. Report on PostAdoption Services in the States. Washington, D.C.: The Association of Administrators of the Interstate Compact on Adoption and Medical Assistance, Inc., 2000.

U.S. Department of Health and Human Services, Administration for Children and Families, Administration on Children, Youth and Families, Children's Bureau. Child Welfare Outcomes 1999: Annual Report. Washington, D.C., n.d.

Wulczyn, Fred H., and Kristin Brunner Hislop. Foster Care Dynamics in Urban and Non-Urban Counties. An issue paper from the Chapin Hall Center for Children at the University of Chicago at the request of the U.S. Department of Health and Human Services. February 2002.

Wulczyn, Fred H., and Kristin Brunner Hislop. Growth in the Adoption Population. An issue paper from the Chapin Hall Center for Children at the University of Chicago at the request of the U.S. Department of Health and Human Services. March 2002.

Wulczyn, Fred H., Kristen Brunner Hislop, and Robert M. Goerge. An Update from the Multistate Foster Care Data Archive: Foster Care Dynamics 1983-1998. Chicago: Chapin Hall Center for Children at the University of Chicago, 2000. 


\section{Related GAO Products}

Child Welfare: New Financing and Service Strategies Hold Promise, but Effects Unknown. GAO/T-HEHS-00-158. Washington, D.C.: July 20, 2000.

Foster Care: HHS Should Ensure That Juvenile Justice Placements Are Reviewed. GAO/HEHS-00-42. Washington, D.C.: June 9, 2000.

Foster Care: States' Early Experiences Implementing the Adoption and Safe Families Act. GAO/HEHS-00-1. Washington, D.C.: December 22, 1999.

Foster Care: HHS Could Better Facilitate the Interjurisdictional Adoption Process. GAO/HEHS-00-12. Washington, D.C.: November 19, 1999.

Foster Care: Effectiveness of Independent Living Services Unknown. GAO/HEHS-00-13. Washington, D.C.: November 5, 1999.

Foster Care: Kinship Care Quality and Permanency Issues. GAO/HEHS-99-32. Washington, D.C.: May 6, 1999.

Foster Care: Increases in Adoption Rates. GAO/HEHS-99-114R. Washington, D.C.: April 20, 1999.

Juvenile Courts: Reforms Aim to Better Serve Maltreated Children. GAO/HEHS-99-13. Washington, D.C.: January 11, 2000.

Child Welfare: Early Experiences Implementing a Managed Care Approach. GAO/HEHS-99-8. Washington, D.C.: October 21, 1998.

Foster Care: Agencies Face Challenges Securing Stable Homes for Children of Substance Abusers. GAO/HEHS-98-182. Washington, D.C.: September 30, 1998.

Foster Care: State Efforts to Improve the Permanency Planning Process Show Some Promise. GAO/HEHS-97-73. Washington, D.C.: May 7, 1997.

Child Welfare: States' Progress in Implementing Family Preservation and Support Activities, GAO/HEHS-97-34. Washington, D.C.: February 18, 1997.

Permanency Hearings for Foster Children. GAO/HEHS-97-55R. Washington, D.C.: January 30, 1997. 
Child Welfare: Complex Needs Strain Capacity to Provide Services. GAO/HEHS-95-208. Washington, D.C.: September 26, 1995.

Child Welfare: HHS Begins to Assume Leadership to Implement National and State Systems. GAO/AIMD-94-37. Washington, D.C.: June 8, 1994. 



\section{GAO’s Mission}

The General Accounting Office, the investigative arm of Congress, exists to support Congress in meeting its constitutional responsibilities and to help improve the performance and accountability of the federal government for the American people. GAO examines the use of public funds; evaluates federal programs and policies; and provides analyses, recommendations, and other assistance to help Congress make informed oversight, policy, and funding decisions. GAO's commitment to good government is reflected in its core values of accountability, integrity, and reliability.

\section{Obtaining Copies of GAO Reports and Testimony}

The fastest and easiest way to obtain copies of GAO documents at no cost is through the Internet. GAO's Web site (www.gao.gov) contains abstracts and fulltext files of current reports and testimony and an expanding archive of older products. The Web site features a search engine to help you locate documents using key words and phrases. You can print these documents in their entirety, including charts and other graphics.

Each day, GAO issues a list of newly released reports, testimony, and correspondence. GAO posts this list, known as "Today's Reports," on its Web site daily. The list contains links to the full-text document files. To have GAO e-mail this list to you every afternoon, go to www.gao.gov and select "Subscribe to daily E-mail alert for newly released products" under the GAO Reports heading.

\section{Order by Mail or Phone}

The first copy of each printed report is free. Additional copies are $\$ 2$ each. A check or money order should be made out to the Superintendent of Documents. GAO also accepts VISA and Mastercard. Orders for 100 or more copies mailed to a single address are discounted 25 percent. Orders should be sent to:

\section{U.S. General Accounting Office \\ 441 G Street NW, Room LM \\ Washington, D.C. 20548}

$\begin{array}{lll}\text { To order by Phone: } & \text { Voice: } & \text { (202) } 512-6000 \\ & \text { TDD: } & (202) 512-2537 \\ & \text { Fax: } & \text { (202) } 512-6061\end{array}$

\section{To Report Fraud, Waste, and Abuse in Federal Programs} Contact:

Web site: www.gao.gov/fraudnet/fraudnet.htm E-mail: fraudnet@gao.gov Automated answering system: (800) 424-5454 or (202) 512-7470 